\title{
Pigment-based chloroplast types in dinoflagellates
}

\author{
Manuel Zapata ${ }^{1, \dagger}$, Santiago Fraga ${ }^{2}$, Francisco Rodríguez ${ }^{2, *}$, José L. Garrido ${ }^{1}$ \\ ${ }^{1}$ Instituto de Investigaciones Marinas, CSIC, c/ Eduardo Cabello 6, 36208 Vigo, Spain \\ ${ }^{2}$ Instituto Español de Oceanografía, Subida a Radio Faro 50, 36390 Vigo, Spain
}

\begin{abstract}
Most photosynthetic dinoflagellates contain a chloroplast with peridinin as the major carotenoid. Chloroplasts from other algal lineages have been reported, suggesting multiple plastid losses and replacements through endosymbiotic events. The pigment composition of 64 dinoflagellate species (122 strains) was analysed by using high-performance liquid chromatography. In addition to chlorophyll (chl) $a_{1}$, both $\mathrm{chl} c_{2}$ and divinyl protochlorophyllide occurred in chl $c$-containing species. Chl $C_{1}$ co-occurred with chl $C_{2}$ in some peridinin-containing (e.g. Gambierdiscus spp.) and fucoxanthin-containing dinoflagellates (e.g. Kryptoperidinium foliaceum). Chl $C_{3}$ occurred in dinoflagellates whose plastids contained 19'-acyloxyfucoxanthins (e.g. Karenia mikimotoi). Chl $b$ was present in green dinoflagellates (Lepidodinium chlorophorum). Based on unique combinations of chlorophylls and carotenoids, 6 pigment-based chloroplast types were defined: Type 1: peridinin/dinoxanthin/chl $C_{2}$ (Alexandrium minutum); Type 2: fucoxanthin/ 19'-acyloxy fucoxanthins/4-keto-19'-acyloxy-fucoxanthins/gyroxanthin diesters/chl $c_{2}, c_{3}$, monogalactosyl-diacylglycerol-chl $C_{2}$ (Karenia mikimotoi); Type 3: fucoxanthin/19'-acyloxyfucoxanthins/gyroxanthin diesters/chl $C_{2}, C_{3}$ (Karlodinium veneficum); Type 4: fucoxanthin/chl $C_{1}, C_{2}(K$. foliaceum); Type 5: alloxanthin/chl $c_{2}$ /phycobiliproteins (Dinophysis tripos); Type 6: neoxanthin/ violaxanthin/a major unknown carotenoid/chl $b$ (Lepidodinium chlorophorum). While plastids with peridinin, and probably those with chl $b$, originated by secondary endosymbiosis, the other chloroplast types were obtained through tertiary endosymbiosis. Chloroplast types corresponded with evolutionary lineages within dinoflagellates. Caution must be observed when only peridinin is used for tracking photosynthetic dinoflagellates in field samples. The additional marker pigments offer oceanographers greater power for detecting dinophytes in mixed populations.
\end{abstract}

KEY WORDS: Dinophyta - Chlorophyll $c$ pigments · Novel fucoxanthin-related pigments · Gyroxanthin diester pigments $\cdot$ Chemotaxonomy $\cdot$ Dinoflagellate chloroplast types $\cdot$ Plastid origin Oceanography Resale or republication not permitted without written consent of the publisher

\section{INTRODUCTION}

Dinoflagellates are a diverse trophic group of alveolate protists with around $50 \%$ of autotrophic organisms with a distinct grade of mixotrophy (Jeong et al. 2005). Most photosynthetic species contain a chloroplast surrounded by 3 membranes with chlorophyll (chl) $C_{2}$ and peridinin as major accessory pigments (Jeffrey et al. 1975).

Several features make autotrophic dinoflagellates unique: (1) the presence of a water-soluble light-harvesting protein, i.e. the extrinsic peridinin-chl a-pro- tein located in the chloroplast thylakoid lumen (Hofmann et al. 1996, Hiller 1999), which occurs in several species together with the ubiquitous intrinsic peridinin-chl a-chl $\quad c_{2}$ membrane-bound light-harvesting protein (Macpherson \& Hiller 2003); (2) the presence of a proteobacterial form of the key enzyme in photosynthesis, the ribulose bisphosphate carboxylase/oxidase (Rubisco), the so-called form II Rubisco (Morse et al. 1995, Rowan et al. 1996) which is nuclear-encoded; (3) the gain of tertiary plastids in certain autotrophic dinoflagellates (Saldarriaga et al. 2001). 
Some photosynthetic dinoflagellates are toxin producers, and the monitoring of these species is the main target of harmful algal bloom (HAB) programmes around the world (e.g. GEOHAB: www. geohab.info). In consequence, taxonomists and oceanographers have sought procedures for the rapid detection and identification of toxic species (see Hallegraeff et al. 2003). Among these techniques, the use of chloroplast pigments as fingerprints of phytoplankton taxa (Jeffrey \& Vesk 1997, Jeffrey et al. 1999) constitutes a useful approach to study the plastid origin and taxonomy of dinoflagellate species. In this context, the presence of peridinin, an allenic trinor carotenoid (i.e. having a $\mathrm{C}_{37}$-skeleton instead of the common $\mathrm{C}_{40}$-xanthophylls), has been considered a distinctive feature in photosynthetic dinoflagellates (see Bjørnland 1990, Liaaen-Jensen 1998). Although the occurrence of peridinin-containing chloroplasts is widespread within autotrophic dinoflagellates, the occurrence of fucoxanthin-containing dinoflagellates was observed in earlier studies (see Jeffrey et al. 1975). Later, several dinoflagellates with different pigment patterns were detected: first, a marine dinoflagellate containing 19'-hexanoyloxyfucoxanthin as the main carotenoid (Tangen \& Bjørnland 1981), then a chl $b$-containing 'green' dinoflagellate (Watanabe et al. 1987), which was further described as Lepidodinium viride (Watanabe et al. 1990), and finally autotrophic Dinophysis species with cryptophyceantype phycobiliproteins (see Geider \& Gunter 1989, Hewes et al. 1998). Information on chloroplast pigments has usually been reported in new descriptions of dinoflagellates (e.g. Fraga et al. 1995, 2008, 2011, Elbrächter \& Schnepf 1996, Bolch et al. 1999, Daugbjerg et al. 2000, Montresor et al. 2003, de Salas et al. 2003, 2004, 2005, Garcés et al. 2006, Tillmann et al. 2009, Sampedro et al. 2011).

Methodological improvements in high-performance liquid chromatography (HPLC) pigment analysis (revised by Jeffrey et al. 1999, Garrido \& Zapata 2006) have enabled us to detect new $\mathrm{chl} c$ pigments and fucoxanthin acyloxy derivatives and to obtain a more accurate distribution pattern of known pigments. An example of this is the description of 8 pigmentary types in Haptophyta (Zapata et al. 2004).

Here we report the pigment composition of 64 dinoflagellate species (122 strains) obtained by HPLC. Six pigment-based chloroplast types are described and compared with other algal lineages. Pigment diversity found in photosynthetic dinoflagellates provides clues both for inferring phylogenetic relationships and tracing the distribution and abundance of dinoflagellates in coastal and open-ocean waters.

\section{MATERIALS AND METHODS}

\author{
Algal cultures
}

Dinoflagellate cultures were obtained from the Culture Collection of the Instituto Español de Oceanografía (CCVIEO, Vigo, Spain), the ProvasoliGuillard National Center for Marine Algae and Microbiota (NCMA - formerly CCMP - Bigelow Laboratory for Ocean Sciences, West Boothbay Harbor, Maine, USA) and the CSIRO Collection of Living Microalgae (CCLM, Hobart, Australia). Most cultures were grown in L1 medium (Guillard \& Hargraves 1993), with the exception of the CSIRO strains which were grown in GSe medium (Blackburn et al. 1989). The species, strain numbers, collection site and isolator are listed in Table $\mathrm{S} 1$ in the supplement at www.int-res.com/articles/suppl/m465p033_supp. pdf. Light irradiances were 60 to $90 \mu \mathrm{mol}$ quanta $\mathrm{m}^{-2}$ $\mathrm{s}^{-1}$ on 12:12 h light:dark cycles for all strains except Dinophysis $\left(150 \mu \mathrm{mol}\right.$ quanta $\left.\mathrm{m}^{-2} \mathrm{~s}^{-1}\right)$. Cultures of Dinophysis species (D. acuminata, D. acuta, D. caudata and $D$. tripos) were established in diluted $(1 / 20)$ L1-Si medium by feeding them the phototrophic ciliate Mesodinium rubrum (= Myrionecta rubra), fed with the cryptophyte Teleaulax sp. (Park et al. 2006).

\section{Sample preparation}

Cultures were examined by light microscopy before HPLC pigment analysis to ensure proper identification and that the cells were healthy and without malformations. Cells were harvested 2 to $4 \mathrm{~h}$ into the light cycle from cultures actively growing a few days after being transferred. Due to the great diversity of species being analysed, variable volumes of culture (typically $10 \mathrm{ml}$ ), depending on the species, were filtered onto Whatman GF/F filters under reduced pressure until some colour was observed on the filter. Filters were frozen immediately at $-20^{\circ} \mathrm{C}$.

\section{Pigment extraction}

Frozen filters were extracted under low light in polytetrafluoroethylene (PTFE)-lined screw capped tubes with $5 \mathrm{ml} 90 \%$ acetone using a stainless steel spatula for filter grinding. The tubes were chilled in a beaker of ice and sonicated for $5 \mathrm{~min}$ in an ultrasonic bath. Extracts were then filtered through $25 \mathrm{~mm}$ diameter syringe filters (MFS HP020, $25 \mathrm{~mm}$, and $0.20 \mu \mathrm{m}$ pore size, hydrophilic PTFE) to remove cell 
and filter debris. An aliquot $(0.5 \mathrm{ml})$ of acetone extract was mixed with $0.2 \mathrm{ml}$ of water, and $200 \mu \mathrm{l}$ were immediately injected. This procedure avoids peak distortion of early eluting peaks (Zapata \& Garrido 1991) and prevents the loss of non-polar pigments prior to injection (Latasa et al. 2001).

\section{HPLC analysis}

Pigments were separated using a Waters Alliance HPLC System (Waters Corporation) consisting of a 2695 separations module, a Waters 996 diode-array detector (1.2 nm optical resolution) and a Waters 474 scanning fluorescence detector. Pigment separation was performed using the HPLC method of Zapata et al. (2000), with a reformulated mobile phase A. The column was a $\mathrm{C}_{8}$ Waters Symmetry $(150 \times 4.6 \mathrm{~mm}$, $3.5 \mu \mathrm{m}$ particle size, $100 \AA$ pore size). Eluent A was methanol:acetonitrile:0.025 $\mathrm{M}$ aqueous pyridine (50: 25:25 by vol.). Eluent B was methanol:acetonitrile: acetone (20:60:20 by vol.). The elution gradient was as follows: (time (min): \%B) $t_{0}: 0 \%, t_{22}: 40 \%, t_{28}: 95 \%$, $t_{37}: 95 \%, t_{40}: 0 \%$. Flow rate was $1.0 \mathrm{ml} \mathrm{min}^{-1}$, and column temperature was fixed at $25^{\circ} \mathrm{C}$ using a Peltiercolumn thermostat (Jet-Stream Plus). Solvents were HPLC grade (Romil-SpS ${ }^{\mathrm{TM}}$ ), pyridine was reagent grade (Merck). CSIRO strains were analysed following the procedure described by Zapata et al. (2004).

\section{Pigment identification}

Pigments were identified either by co-chromatography with authentic standards obtained from SCOR reference cultures (Jeffrey et al. 1997) and diode-array spectroscopy (see Zapata et al. 2000). After checking for peak purity, spectral information was compared with a library of chlorophyll and carotenoid spectra from pigments prepared from phytoplankton cultures. Compounds such as 4 -keto19'-hexanoyloxyfucoxanthin and chl $c_{1}$-like Kryptoperidinium-type were isolated as described previously (Garrido \& Zapata 1998, Egeland et al. 2000, Zapata et al. 2006). Novel carotenoids from Karenia mikimotoi were tentatively identified (Garrido et al. unpubl.). Pigment nomenclature and abbreviations were as suggested by SCOR WG 78 (Jeffrey \& Mantoura 1997). For monogalactosyl-diacylglycerol (MGDG)-chl $c$-like pigments whose molecular structures have been elucidated (Garrido et al. 2000), the nomenclature was MGDG-chl $\mathrm{C}_{2}$-Chrysochromulina polylepis-type (Zapata et al. 2001). For chlorophylls whose molecular structure is unknown, the pigment name includes a reference to the most likely chl $C$ chromophore ( $\mathrm{chl} C_{1}$ - or $C_{2}$-like), and a mention of the species in which the pigment was initially detected (e.g. chl $C_{2}$-like Pavlova gyrans-type, chl $C_{1}$-like EXanthemachrysis-type). For tentative identification of unknown pigments, the chromatographic behaviour was studied using 2 HPLC systems: the polymeric $\mathrm{C}_{18}$ method of Garrido \& Zapata (1997) and the $\mathrm{C}_{8}$ method of Zapata et al. (2000) were compared.

\section{Pigment quantification}

HPLC calibration by external standards was performed using chlorophyll and carotenoid standards isolated from microalgal cultures (see Zapata et al. 2000), as well as pigments supplied by DHI (Denmark). The molar extinction coefficients $\left(\varepsilon_{i} \mathrm{l} \mathrm{mol}^{-1}\right.$ $\mathrm{cm}^{-1}$ ) provided by Jeffrey (1997) were used for pigment quantification. For chl $c$-like pigments whose molar extinction coefficients are not available (i.e. chl $C_{3}$, chl $C_{1}$-like Exanthemachrysis-type and chl $C_{2}$-like Pavlova gyrans-type) the mean of the extinction coefficients for chl $c_{1}$ and $c_{2}$ at the blue absorption band (see Jeffrey et al. 1997) was used. The MGDG-chl $c_{2}$ were quantified by using the molar extinction coefficient of the chl $C_{2}$ chromophore. For fucoxanthinrelated compounds (i.e. acyloxy and keto derivatives), the molar extinction coefficient for fucoxanthin was used, following the recommendations of Jeffrey et al. (1997), even though the absorption spectra of fucoxanthin-derivatives differ slightly from those of the parent compounds. Thus pigment to chl a ratios are expressed on a molar base $\left(\mathrm{molmol}^{-1}\right)$.

\section{RESULTS}

\section{Chromatographic resolution and pigment identities}

The peak number of the pigments together with the retention time and their visible absorption maxima in eluent is shown in Table 1. Of the 63 pigments, 44 were well known chlorophylls and carotenoids previously compiled by Jeffrey et al. (1997). Structures of chl $C$ pigments not included in the above review may be found in Helfrich et al. (1999) and Zapata et al. (2006), and structures of algal carotenoids in Bjørnland et al. (2000) and Egeland et al. (2000). The rest of pigments were unknown chl $c$ like compounds and carotenoids present in trace amounts. 
Table 1. Elution order and visible absorption characteristics of pigments in eluent from dinophyte cultures. Wavelengths given in parentheses denote shoulders. Occurrence across the 6 pigment-based chloroplast types is indicated. MGDG: monogalactosyl-diacylglycerol

\begin{tabular}{|c|c|c|c|c|c|c|c|}
\hline $\begin{array}{l}\text { Peak } \\
\text { no. }\end{array}$ & Pigment & $\begin{array}{l}\text { Chloroplast } \\
\text { type }\end{array}$ & Abbreviation & $\begin{array}{l}\text { Time } \\
(\min )\end{array}$ & \multicolumn{3}{|c|}{$\lambda$ maxima in eluent } \\
\hline 1 & Peridininol & 1 & Perid-ol & 5.66 & & 477 & \\
\hline 2 & Unknown carotenoid $\lambda_{\max } 465 \mathrm{~nm}$ & 1 & Unk-car465 & 7.28 & & 465 & \\
\hline 3 & Chlorophyll $C_{2}$-like Pavlova gyrans-type & 4 & Chl $C_{2}$-like $P g$ & 7.69 & 457 & 586 & 634 \\
\hline 4 & Chlorophyll $c_{3}$ & 2,3 & $\mathrm{Chl} C_{3}$ & 8.02 & 458 & 591 & $(629)$ \\
\hline 5 & Chlorophyll $c_{1}$-like Exanthemachrysis-type & 4 & Chl $C_{1}$-like $E g$ & 8.31 & 453 & 585 & 635 \\
\hline 6 & Unknown chlorophyll $C_{2}$-like & 1 & Chl $C_{2}$-like 450 & 8.86 & 450 & 583 & 631 \\
\hline 7 & Chlorophyllide $a$ & $1-6$ & Chlide $a$ & 10.47 & 430 & 619 & 663 \\
\hline 8 & Divinyl protochlorophyllide a & $1-6$ & MgDVP & 10.83 & 440 & 574 & 628 \\
\hline 9 & Chlorophyll $C_{2}$ & $1-5$ & $\mathrm{Chl} \mathrm{C}_{2}$ & 11.75 & 453 & 585 & 634 \\
\hline 10 & Chlorophyll $c_{1}$ & 1,4 & $\mathrm{Chl} C_{1}$ & 12.34 & 448 & 583 & 632 \\
\hline 11 & Peridinin & 1 & Peri & 13.85 & & 475 & \\
\hline 12 & Peridinin-like & 1 & Peri-like & 14.33 & & 478 & \\
\hline 13 & Keto-19'-butanoyloxyfucoxanthin-like & 2 & But-fuco-like-1 & 15.68 & & 448 & 471 \\
\hline 14 & 4-keto-19'-butanoyloxyfucoxanthin & 2 & But-fuco-like-2 & 16.29 & & 448 & 470 \\
\hline 15 & Unknown carotenoid $\lambda_{\max } 447$ & 1 & Unk-car447-CC & 16.39 & $(424)$ & 447 & 477 \\
\hline 16 & 19'-butanoyloxyfucoxanthin & 2,3 & But-fuco & 17.21 & & 447 & 470 \\
\hline 17 & All-trans neoxanthin & 6 & $t$-neo & 17.52 & 416 & 442 & 470 \\
\hline 18 & Heteroxanthin-like & 3 & Het-like Th & 17.77 & 419 & 443 & 471 \\
\hline 19 & Fucoxanthin & $2-4$ & Fuco & 18.27 & & 451 & \\
\hline 20 & 9'-cis neoxanthin & 6 & Neo & 19.46 & 413 & 439 & 466 \\
\hline 21 & Astaxanthin & 1 & Asta & 19.58 & & 480 & \\
\hline 22 & Keto-hexanoyloxyfucoxanthin-like & 2 & 4k-hex-fuco-like & 19.61 & & 448 & 472 \\
\hline 23 & 4-keto-19'-hexanoyloxyfucoxanthin & 2 & $4 \mathrm{k}$-hex-fuco & 20.34 & & 448 & 472 \\
\hline 24 & Violaxanthin & 1,6 & Viola & 20.80 & 415 & 441 & 470 \\
\hline 25 & Pyrrhoxanthin & 1 & Pyrrho & 21.12 & & 471 & \\
\hline 26 & $19^{\prime}$-hexanoyloxyfucoxanthin & 2,3 & Hex-fuco & 21.22 & & 447 & 471 \\
\hline 27 & Diadinochrome & 1 & Diadchr & 22.90 & $(410)$ & 430 & 458 \\
\hline 28 & Diadinoxanthin & $1-4$ & Diadino & 23.77 & $(422)$ & 448 & 477 \\
\hline 29 & Dinoxanthin & 1 & Dino & 24.93 & 418 & 442 & 471 \\
\hline 30 & Unknown carotenoid $\lambda_{\max } 463$ & 4 & Unk-car463-Kf & 24.12 & & 463 & \\
\hline 31 & cis-fucoxanthin & $2-4$ & $C$-fuco & 24.61 & & 442 & \\
\hline 32 & Antheraxanthin & 6 & Anth & 24.77 & $(422)$ & 447 & 475 \\
\hline 33 & 19'-acyloxyfucoxanthin-like & 3 & Acyl-fuco-like & 25.26 & & 448 & 471 \\
\hline 34 & Unknown carotenoid $\lambda_{\max } 453$ & 4 & Unk-car453-Kf & 25.42 & $(428)$ & 453 & $(482)$ \\
\hline 35 & Alloxanthin & 5 & Allo & 26.06 & $(428)$ & 454 & 483 \\
\hline 36 & Lycopene-like & 1 & Lyco-like-1 & 26.30 & 451 & 476 & 509 \\
\hline 37 & Diatoxanthin & $1-4$ & Diato & 26.62 & $(426)$ & 453 & 481 \\
\hline 38 & Unknown carotenoid $\lambda_{\max } 447$ & 4 & Unk-car447-Kf & 27.10 & $(420)$ & 447 & $(472)$ \\
\hline 39 & Zeaxanthin & $1-4,6$ & Zea & 27.45 & $(429)$ & 454 & 480 \\
\hline 40 & Unknown carotenoid from Lepidodinium chlorophorum & 6 & Unk-car443-LC & 27.65 & 420 & 443 & 472 \\
\hline 41 & Lycopene-like & 1,2 & lyco-like-2 & 28.00 & $(452)$ & 476 & 507 \\
\hline 42 & Unknown carotenoid from $L$. chlorophorum & 6 & Unk-car443b- $L c$ & 28.12 & 420 & 443 & 472 \\
\hline 43 & Gyroxanthin diester-like & 2,3 & GyrE-like & 28.58 & $(418)$ & 445 & 472 \\
\hline 44 & Canthaxanthin & 1,3 & Cantha & 29.30 & & 472 & \\
\hline 45 & Gyroxanthin diester-2 & 2,3 & GyrE (12:0) & 29.56 & $(418)$ & 445 & 472 \\
\hline 46 & Gyroxanthin diester-3 & 2,3 & GyrE (14:0) & 30.46 & (419) & 445 & 471 \\
\hline 47 & Crocoxanthin & 5 & Croco & 30.93 & $(431)$ & 447 & 476 \\
\hline 48 & Hydroxyl echinenone & 4 & Hydro-echin & 31.26 & & 468 & \\
\hline 49 & $\beta$-cryptoxanthin & 1 & $\beta$-crypto & 31.41 & $(426)$ & 454 & 480 \\
\hline 50 & Chlorophyll $b$ & 6 & Chl $b$ & 31.67 & 461 & 597 & 647 \\
\hline 51 & Chlorophyll $c_{2}$ MGDG from Karlodinium armiger & 3 & MGDG-chl $C_{2}-K a$ & 32.17 & 454 & 584 & 634 \\
\hline 52 & Chlorophyll a allomer & $1-6$ & Chl a allomer & 32.74 & 420 & 615 & 662 \\
\hline 53 & Chlorophyll $C_{2}$ MGDG from Emiliania huxleyi & 3 & MGDG-chl $c_{2}-E h$ & 32.98 & 454 & 584 & 634 \\
\hline 54 & Chlorophyll a & $1-6$ & Chl a & 33.29 & 431 & 617 & 662 \\
\hline 55 & Chlorophyll a epimer & $1-6$ & Chl $a^{\prime}$ & 33.51 & 431 & 617 & 662 \\
\hline 56 & $\begin{array}{l}\text { Chlorophyll } c_{2} \text { MGDG from Chrysochromulina } \\
\text { polylepis }\end{array}$ & 2,3 & MGDG-chl $C_{2}-C p$ & 33.74 & 454 & 584 & 634 \\
\hline 57 & $\beta, \psi$-carotene-like & 4 & $\beta \psi$-car-like & 34.28 & $(437)$ & 463 & 492 \\
\hline 58 & $\beta, \psi$-carotene & 4 & $\beta \psi$-car & 34.48 & $(437)$ & 463 & 493 \\
\hline 59 & Pheophytin a & $1-6$ & Pheo a & 35.32 & 409 & 609 & 665 \\
\hline 60 & Chlorophyll $c_{2}$ MGDG from Takayama cf. helix & 3 & MGDG-chl $c_{2}-T h$ & 35.45 & 455 & 583 & 634 \\
\hline 61 & $\beta, \varepsilon$-carotene & $2-6$ & $\beta \varepsilon$-car & 35.49 & $(422)$ & 447 & 475 \\
\hline 62 & $\beta, \beta$-carotene & $1-5$ & $\beta \beta$-car & 35.67 & $(426)$ & 454 & 480 \\
\hline 63 & Cis- $\beta, \beta$-carotene & 4 & $c-\beta \beta$-car & 35.94 & $(426)$ & 452 & 478 \\
\hline
\end{tabular}




\section{Pigment composition: chlorophylls}

Thirteen chlorophylls, i.e. chl $a, b$ and 11 chl $c$-type pigments ( 7 polar chl $c$ and 4 non-polar chl $C_{2}$-like), were detected. Chl $C_{2}$ (peak 9) together with divinyl protochlorophyllide (MgDVP; peak 8) were always present in chl $c$-containing dinoflagellates; other $\mathrm{chl}$ $c$ pigments showed a heterogeneous distribution, in some cases at trace levels. Chl $C_{1}$ (peak 10) was detected in several peridinin-containing dinoflagellates (e.g. Peridinium aciculiferum, Gambierdiscus excentricus), as well as in the fucoxanthin-containing dinoflagellates Durinskia baltica and Kryptoperidinium foliaceum. Chl $c_{3}$ (peak 4) was only present in the genera Karenia, Karlodinium and Takayama (Family Kareniaceae). The MGDG-chl $\mathrm{C}_{2}$-Chrysochromulina polylepis-type (peak 56) was a minor peak in Karenia spp., some Karlodinium species ( $K$. armiger, $K$. decipiens) and $T$. cf. helix. Two novel non-polar chl $C_{2}$-like pigments were also detected, the first (peak 51) in K. armiger eluted just before the MGDG-chl $C_{2}$ Emiliania huxleyi-type (peak 53), and the second (peak 60) in T. cf. helix at a higher retention time than the MGDG-chl $C_{2}$-C. polylepis-type (peak 56). Red-shifted chl $c_{1}$ (peak 5) and chl $c_{2}$ (peak 3 ), having absorption spectra and chromatographic behaviour similar to those of chl $c_{1}$-like from Exanthemachrysis gayraliae (Van Lenning et al. 2003) and chl $C_{2}$-like from Pavlova gyrans (Fawley 1989), occurred in D. baltica and $K$. foliaceum. Blue-shifted chl $C_{2}$-like pigment (peak $6, \lambda_{\max }=450 \mathrm{~nm}$ ) was detected as traces in several peridinin-containing dinoflagellates. Chl $b$ (peak 50) was restricted to Lepidodinium (PT) chlorophorum.

\section{Carotenoid composition}

Among the 47 carotenoids detected in the dinoflagellates studied (see Table 1), 31 were well-known compounds and 16 were unknown compounds (most of them occurring at minor or trace levels, probably optical or geometrical isomers of known carotenoids). Results from electron visible absorption and chromatographic behaviour in 2 HPLC systems with distinct selectivity, i.e. the $\mathrm{C}_{8}$ HPLC and the polymeric $\mathrm{C}_{18}$ method of Garrido \& Zapata (1997), were taken into account for tentative identification (data not shown).

Peridininol (peak 1), the deacetylated derivative of peridinin (peak 11), was the most polar carotenoid detected. It co-occurred with peridinin as well as a minor peridinin-like pigment (peak 12) eluting just after peridinin. Diadinochrome (peak 27), the 5,8epoxide rearrangement of diadinoxanthin, diadinoxanthin (peak 28), dinoxanthin (peak 29) and diatoxanthin (peak 37) completed the major carotenoids detected in peridinin-containing dinoflagellates. Other carotenoids that were less abundant or restricted to a few species were: a diadinoxanthin-like pigment (peak 15) detected in Coolia canariensis (VGO775), astaxanthin (peak 21), violaxanthin (peak 24), pyrrhoxanthin (peak 25), trans-neoxanthin (peak 17) and zeaxanthin (peak 39).

Carotenoids of the genus Karenia included 3 novel compounds: peaks 13, 14 and 22. The visible absorption spectra of these carotenoids isolated from $K$. mikimotoi (CCMP429) are shown in Fig. 1; for comparative purposes, visible spectra of 19'-butanoyloxyfucoxanthin (peak 16), 19'-hexanoyloxyfucoxanthin (peak 26) and 4-keto-19'-hexanoyloxyfucoxanthin (peak 23) are also depicted. A major gyroxanthin diester carotenoid (peak 45) occurred in Karenia and Karlodinium species; in addition, a second compound (peak 46) with a similar absorption spectrum was detected in Karlodinium veneficum strains at variable proportions. A third gyroxanthin diester-like pigment (peak 43), less retained than the previous ones, as well as less abundant, was detected in K. mikimotoi.

Alloxanthin (peak 35) and crocoxanthin (peak 47) were detected in Dinophysis acuminata, D. acuta, D. caudata and $D$. tripos; monadoxanthin was absent. Carotenoids of the chl $b$-containing dinoflagellate Lepidodinium chlorophorum included both forms of neoxanthin (all-trans neoxanthin [peak 17] and 9'-cis neoxanthin [peak 20]), violaxanthin (peak 24), antheraxanthin (peak 32), zeaxanthin (peak 39) and a major unknown carotenoid (peak 40).

\section{Pigment-based chloroplast types in dinoflagellates}

According to the pigment composition of the dinoflagellates analysed, 6 pigment-based chloroplast types (hereafter 'chloroplast types') were defined, and representative chromatograms are shown in Fig. 2. Chlorophyll and carotenoid composition of the 6 chloroplast types are summarised in Table 2.

Most dinoflagellates species were peridinin-containing organisms labeled as chloroplast Type 1 ( $71 \%$ of species, $51 \%$ of strains), with chl $c_{2}$ (peak 9) as the major accessory chlorophyll and traces of MgDVP (peak 8). Chl $C_{1}$ (peak 10) was present in some cases at lower concentrations than chl $C_{2}$ (e.g. Gambierdiscus excentricus VGO790, Peridinium aci- 

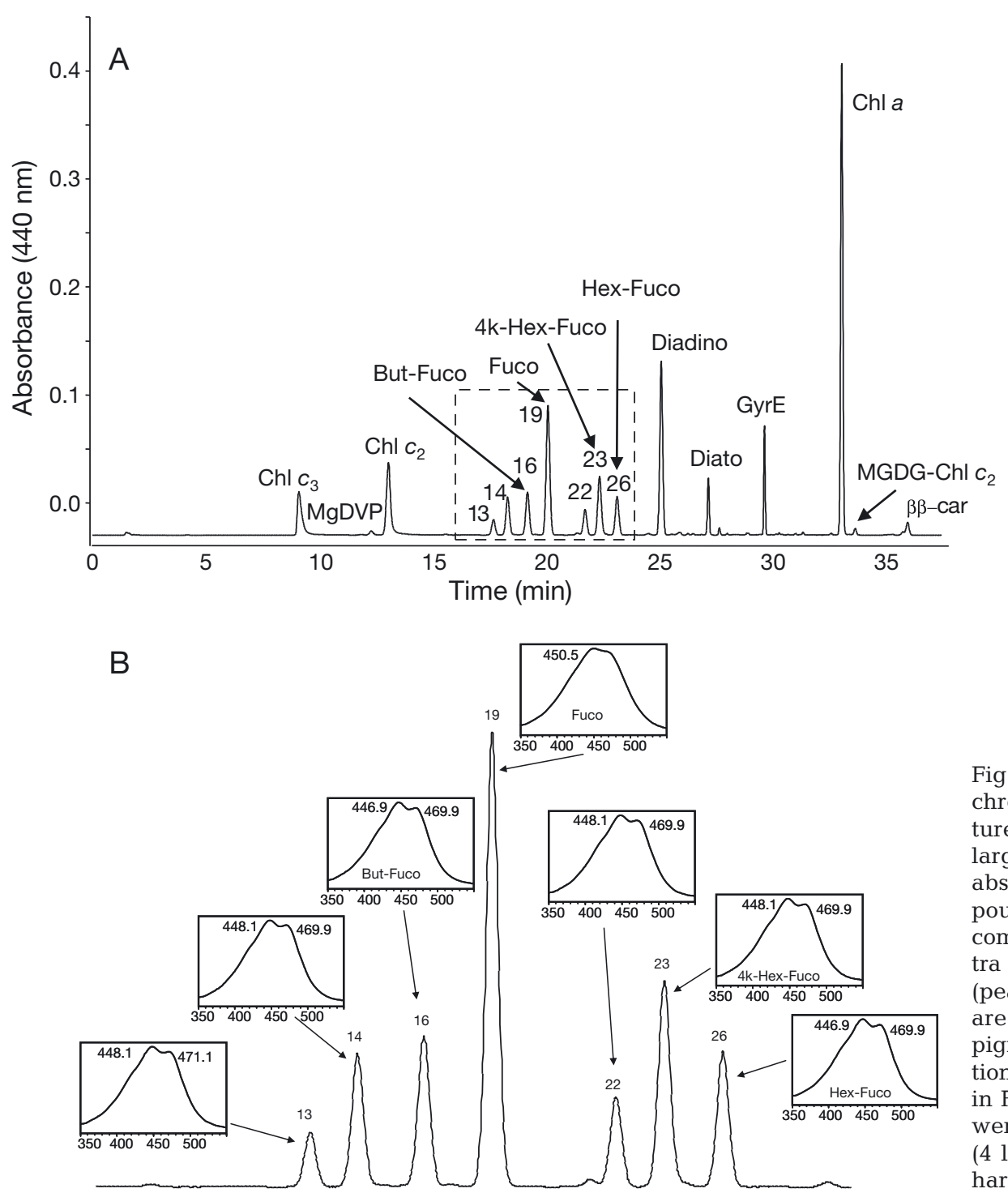

Fig. 1. Karenia mikimotoi. (A) HPLC chromatogram from a massive culture of strain CCMP429. (B) Enlarged section showing the visible absorption spectra of 3 novel compounds (peaks 13, 14 and 22). For comparative purposes, visible spectra of But-fuco (peak 16), Hex-fuco (peak 26) and 4k-Hex-fuco (peak 23) are also depicted (see Table 1 for full pigment names). Pigment proportions cannot be compared with those in Fig. 2 because growth conditions were different in massive cultures (4 l) due to self-shading and longer harvesting periods (10 to $15 \mathrm{~d})$

culiferum PAER-2, Protoceratium reticulatum CCMP1720), although $\mathrm{chl} c_{1}$ was the major $\mathrm{chl} C$ pigment in Gyrodinium uncatenum CS-289/3. The carotenoids peridinin (peak 11) and dinoxanthin (peak 29) were specific to chloroplast Type 1 dinoflagellates. Other carotenoids were diadinoxanthin (peak 28), diadinochrome (peak 27), diatoxanthin (peak 37) and $\beta \beta$-car (peak 62). Overall, 11 genera, including 44 species (83 strains) of the dinoflagellates studied, belonged to chloroplast Type 1 .

Chloroplast Type 2 grouped dinoflagellates with Fuco (peak 19), 19'-acyloxyfucoxanthins and their keto derivatives (up to 6 fucoxanthin-related compounds: peaks 13, 14, 16, 22, 23 and 26), and gyroxanthin diesters (up to 3 compounds: peaks 43, 45 and 46). The array of $\operatorname{chl} C$ included: $\operatorname{chl} C_{2}$ (peak 9), chl $c_{3}$ (peak 4), MgDVP (peak 8) and MGDG-chl $c_{2}$ -
Chrysochromulina polylepis-type (peak 56). Only the genus Karenia (5 species, 8 strains) belonged to chloroplast Type 2. Fucoxanthin (peak 19) was the major carotenoid in $K$. brevis, $K$. mikimotoi and $K$. selliformis, but Hex-fuco (peak 26) was the most abundant carotenoid in $K$. papilonacea and $K$. umbella. Different forms of gyroxanthin diester were tentatively identified: $\mathrm{C}_{12: 0}$ (peak 45), the major form described by Bjørnland et al. (2003), and 2 minor components tentatively assigned as $\mathrm{C}_{14: 0}$ (peak 46), and a less retained gyroxanthin diester-like pigment (peak 43). The fingerprint of chloroplast Type 2 dinoflagellates with six 19'-acyloxyderivatives is unique for the group of 5 Karenia species (8 strains) analysed.

Chloroplast Type 3 resembled Type 2, but it lacked the diverse fucoxanthin pool observed in Karenia species. But-fuco and Hex-fuco were the major acyl- 

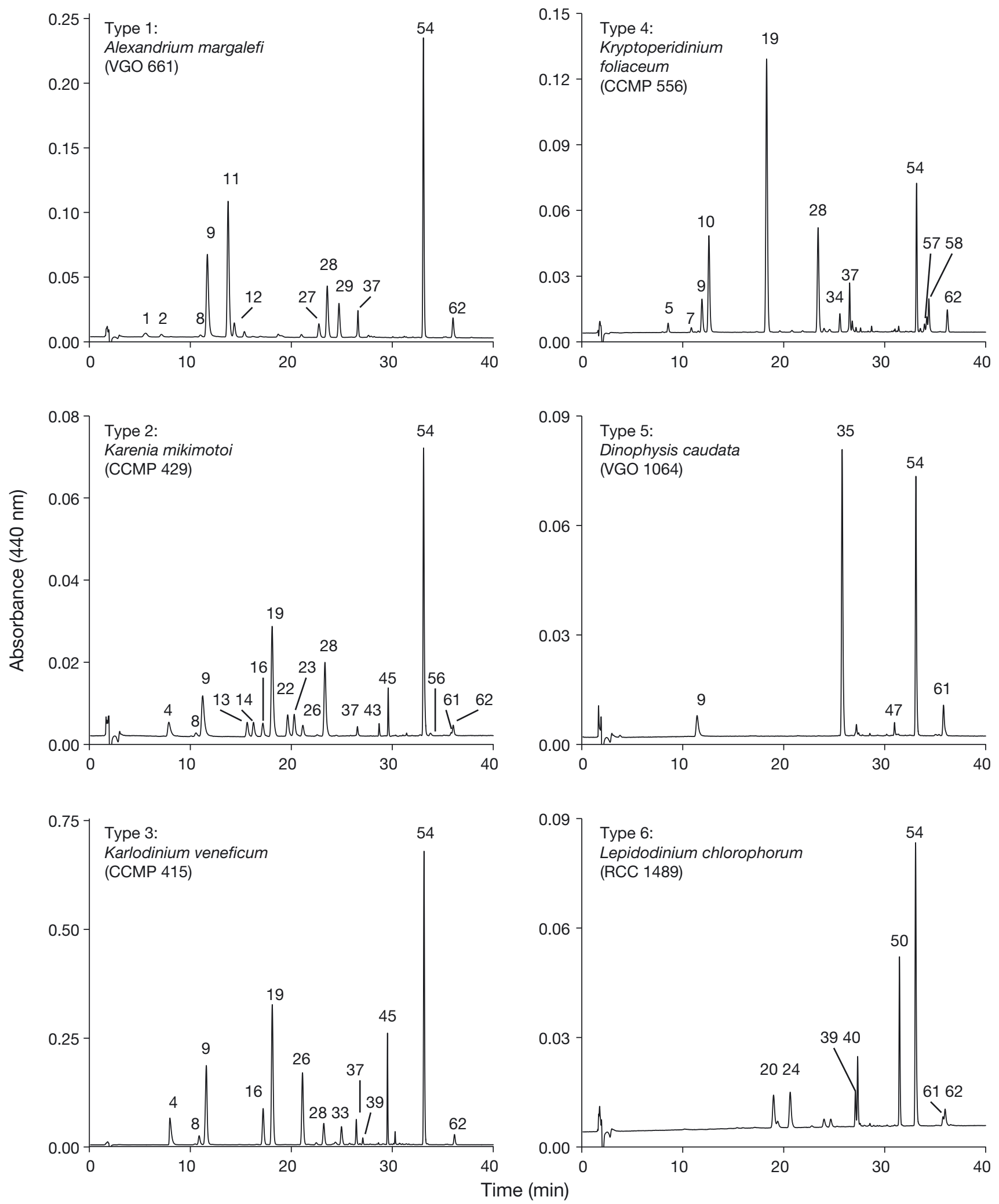

Fig. 2. HPLC chromatograms of dinoflagellates belonging to major chloroplast types. Type 1: Alexandrium margalefi (VGO661); Type 2: Karenia mikimotoi (CCMP429); Type 3: Karlodinium veneficum (CCMP415); Type 4: Kryptoperidinium foliaceum (VGO556); Type 5: Dinophysis caudata (VGO1064); Type 6: Lepidodinium chlorophorum (RCC1489). Detection by absorbance at $440 \mathrm{~nm}$. Peak identifications as in Table 1 
Table 2. Distribution of chlorophylls (chl) and carotenoids among pigment-based chloroplast types in Dinophyta. @: consistent occurrence; O: occasional occurrence. Abbreviations as in Table 1

\begin{tabular}{|c|c|c|c|c|c|c|}
\hline \multirow{2}{*}{ Pigment } & \multicolumn{6}{|c|}{ Pigment-based chloroplast type } \\
\hline & 1 & 2 & 3 & 4 & 5 & 6 \\
\hline Chlorophylls & \multicolumn{5}{|c|}{ 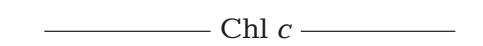 } & Chl $b$ \\
\hline Chl $C_{2}$-like $P g$ & - & - & - & $\bullet$ & - & - \\
\hline Chl $C_{1}$-like $E g$ & - & - & - & 0 & - & \\
\hline $\mathrm{Chl} C_{3}$ & - & 0 & $\bullet$ & - & - & - \\
\hline MgDVP & 0 & 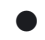 & 0 & 0 & ○ & 0 \\
\hline Chl $C_{2}$ & 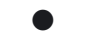 & $\bullet$ & $\bullet$ & 0 & ○ & - \\
\hline Chl $c_{1}$ & O & - & - & 0 & - & - \\
\hline Chl $b$ & - & - & - & - & - & 0 \\
\hline Chl a & ○ & 0 & 0 & 0 & ○ & 0 \\
\hline MGDG-chl $C_{2}$ & - & ○ & O & - & - & - \\
\hline Carotenoids & Peri-type & \multicolumn{3}{|c|}{ —Fuco-type _- } & $\begin{array}{l}\text { Allo- } \\
\text { type }\end{array}$ & $\begin{array}{l}\text { Vio/Neo- } \\
\text { type }\end{array}$ \\
\hline Peridininol & 0 & - & - & - & - & - \\
\hline Unk 1/Unk 2 & 0 & - & - & - & - & - \\
\hline Peridinin & 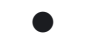 & - & - & - & - & - \\
\hline cis-Peridinin & 0 & - & - & - & - & - \\
\hline Keto-19'-but-fuco-like & - & 0 & - & - & - & - \\
\hline 4-keto-19'-but-fuco & - & 0 & - & - & - & - \\
\hline $19^{\prime}$-but-fuco & - & 0 & 0 & - & - & - \\
\hline Fucoxanthin & - & 0 & 0 & 0 & - & - \\
\hline Keto-19'-hex-fuco-like & - & 0 & - & - & - & - \\
\hline 4-keto-19'-hex-fuco & - & 0 & 0 & - & - & - \\
\hline $19^{\prime}$-hex-fuco & - & 0 & 0 & - & - & - \\
\hline Violaxanthin & - & - & - & 0 & - & 0 \\
\hline Diadinochrome & ○ & - & - & - & - & - \\
\hline Diadinoxanthin & 0 & 0 & 0 & 0 & ○ & - \\
\hline Dinoxanthin & 0 & - & - & - & - & - \\
\hline Alloxanthin & - & - & - & - & 0 & - \\
\hline Diatoxanthin & 0 & 0 & 0 & 0 & 0 & - \\
\hline Zeaxanthin & 0 & 0 & 0 & 0 & - & 0 \\
\hline Unknown carotenoid $L_{C}$ & C - & - & - & - & - & 0 \\
\hline Lycopene-like & 0 & 0 & 0 & 0 & - & 0 \\
\hline Gyroxanthin diester 1 & - & 0 & 0 & - & - & - \\
\hline Gyroxanthin diester 2 & - & 0 & 0 & - & - & - \\
\hline Gyroxanthin diester 3 & - & 0 & 0 & - & - & - \\
\hline$\beta, \psi$-carotene & - & - & - & $\bullet$ & - & $\bullet$ \\
\hline$\beta, \varepsilon$-carotene & - & $\bullet$ & $\bullet$ & 0 & $\bullet$ & 0 \\
\hline$\beta, \beta$-carotene & 0 & 0 & 0 & 0 & 0 & 0 \\
\hline
\end{tabular}

included 2 species from different genera: Durinskia baltica (1 strain) and Kryptoperidinium foliaceum (2 strains). A characteristic feature is the occurrence of $\beta, \psi$ carotene (peak 58). Chl $c_{1}$ (peak 10) was the dominant chl $C$-type pigment, with $\mathrm{chl} C_{2}$ (peak 9) second in importance. Two minor chl $c_{1}$ viz. chl $c_{1}$-like Exanthemachrysis gayraelae-type (peak 5) and chl $C_{2}$-like Pavlova gyrans-type (peak 3), were also detected.

Chloroplast Type 5 included dinoflagellates from the genus Dinophysis (4 species and 4 strains) with cryptophyte-like chloroplasts. Acetylenic alloxanthin (peak 35) was the major carotenoid, together with crocoxanthin (peak 47), and chl $C_{2}$ (peak 9) and MgDVP (peak 8) as the accessory chlorophylls.

Chloroplast Type 6 has green algae-like chloroplast pigments: i.e. the accessory chl $b$ (peak 50), 9' -cis neoxanthin (peak 20), alltrans neoxanthin isomer (peak 17) and violaxanthin (peak 24). Neither lutein nor freeloroxanthin, siphonaxanthin or its esters were detected. The major carotenoid was an unknown compound (peak $40, \lambda_{\max }: 420$, $443,475 \mathrm{~nm}$; band ratio (\% III/II) $=87$ ) eluting after zeaxanthin (peak 39, see Table 1). Using another HPLC method to improve carotenoid separation in Tetraselmis species (Garrido et al. 2009), peak 40 eluted before a lutein standard (data not shown). The 4 strains of Lepidodinium chlorophorum analysed (BAHME100, RCC1488, RCC1489 and Dino16EUH) showed a similar carotenoid profile. oxyderivatives detected in Karlodinium spp. with 19'-acyloxyfucoxanthin-like (peak 33) at trace levels (Acyl-fuco-like:chl $a=0.02$ ) and no keto-19'-acyloxyderivatives. The major form of gyroxanthin diester was the $\mathrm{C}_{12: 0}$ acyl ester at C-19 (peak 45 ), but $\mathrm{C}_{14: 0}$ (peak 46) was also abundant in Karlodinium armiger, $K$. decipiens and $K$. veneficum. However, Takayama cf. helix (VGO341), which was also included in chloroplast Type-3, lacked gyroxanthin diesters. Two genera, with 4 species (11 strains), of the dinoflagellates studied belonged to chloroplast Type 3 .

Chloroplast Type 4, comprising fucoxanthincontaining dinoflagellates with no acyloxyderivatives,

\section{Quantitative pigment data: chlorophyll pigments}

The abundance of chlorophyll and carotenoid pigments expressed as molar ratios with respect to chl a are shown in Tables 3 to 5 (corresponding mass [w:w] ratios are shown in Tables $\mathrm{S} 2$ to $\mathrm{S} 4$ ). Chl $C_{2}$ was the most abundant chl $c$ pigment in chloroplast Types 1 , 2,3 and 5. The chl $C_{2}$ to $\mathrm{chl}$ a ratio in peridinincontaining dinoflagellates (Table 3 ) ranged from 0.03 (Prorocentrum levis) to 0.57 (Amphidinium carterae). The occurrence of MgDVP in trace amounts was a general trait in chl $C$-containing species (ratios not shown in tables). Chl $c_{1}$ occurred in several peridinin- 
containing dinoflagellates (Type 1), usually in traces. Intermediate values were observed in Gambierdiscus excentricus (chl $c_{1}: \mathrm{chl} a=0.06$ ) and Peridinium aciculiferum (0.16), and the highest in Gyrodinium uncatenum ( $\operatorname{chl} c_{1}: \operatorname{chl} a=0.41$ ), where $\operatorname{chl} c_{1}$ was the major chl $c$ pigment ( $\left.\mathrm{chl} c_{1}: c_{2}=1.46\right)$. Chloroplast Types 2 and 3 (Table 4) showed chl $c_{2}$ and $c_{3}$ with chl $c_{3}: \operatorname{chl} c_{2}$ ratios varying from 0.29 to 0.58 . Chloroplast Type 4 (Table 5) contained higher values of $\mathrm{chl} c_{1}$ than $\mathrm{chl} c_{2}$ (chl $c_{1}:$ chl $\left.C_{2}=1.38-2.25\right)$. Chl $c_{1}$-like Exanthemachrysis-type and $\mathrm{chl} \mathrm{C}_{2}$-like Pavlova-type were minor pigments in Kryptoperidinium foliaceum and Durinskia baltica, respectively, representing $\sim 6 \%$ of the chl $c$ pool. MGDG-chl $C_{2}$ Chrysochromulina polylepistype (peak 56) occurred as a minor pigment in Type 2 (MGDG-chl $C_{2}$-C. polylepis-type:chl $a \leq 0.005$ ), and certain Karlodinium species (e.g. K. armiger and $K$. decipiens) were included in chloroplast Type 3.

Finally, chl $b$ :chl a ratios (Type 6, Table 5) varied among the Lepidodinium chlorophorum strains. The ratio was low (0.08) for the North Sea strain (BAHME 100), while the Nervion River isolate (Dino16EUH) showed the highest chl $b$ :chl $a$ ratio (0.74).

\section{Quantitative pigment data: carotenoids}

Peridinin was the major carotenoid in almost all peridinin-containing dinoflagellates (Table 3). Only in a few cases did the Diadino:chl a ratio surpass Peri:chl a ratios, reflecting a high xanthophyll cycle activity. The Peri:chl a ratio (Table 3 ) ranged from 0.54 in Barrufeta bravensis (VGO864) to 2.06 in Coolia canariensis VGO787. If normalised to $\mathrm{chl} C_{2}$, the lower values correspond to Gymnodiniales (Peri:chl $\left.C_{2}=1.60-2.91\right)$ and Peridiniales (Peri:chl $C_{2}=1.39-$ 4.87). Prorocentrales showed higher ratios (Peri:chl $C_{2}$ = 3.51-38.92), especially the benthic, symmetric species of Prorocentrum. Diadinoxanthin was usually the second major carotenoid, with ratios of Diadino: chl a ranging from 0.28, both in Alexandrium pseudogonyaulax VGO706 and in A. catenella AL96, to 1.09 in P. lima PL2V. Dinoxanthin:chl a ratios were rather constant in most strains (mean $\pm \mathrm{SD}=0.18 \pm 0.07$ ), although the ratio ranged from 0.01 (Neoceratium furca Nfurca1) to 0.42 (B. bravensis VGO860).

In chloroplast Type 2 (Table 4), Fuco was the major carotenoid in Karenia brevis, K. mikimotoi and K. selliformis (Fuco:chl $a=0.24-0.34$ ) whereas Hex-fuco was dominant in $K$. papilonacea (Hex-fuco:chl $a=$ 0.29 ) and $K$. umbella (Hex-fuco:chl $a=0.32$; Table 4). The contribution of acyloxyfucoxanthins (6 compounds) to the fucoxanthin total pool varied among strains. The Hex-fuco derivatives were always more abundant than the But-fuco pigments. The fucoxanthin pool in chloroplast Type 3 was formed by Fuco, But-fuco and Hex-fuco with no keto-derivatives. Fuco was the major carotenoid (Table 4 ) in 5 out of 6 Karlodinium veneficum strains (Fuco:chl $a=$ 0.30-0.75), and Hex-fuco was the major carotenoid in $K$. armiger, $K$. decipiens and $K$. veneficum VGO870 (Hex-Fuco:chl $a=0.21-0.45$ ). Takayama cf. helix showed Fuco as major carotenoid (Fuco:chl $a=1.18$ ), with only a minor contribution of Hex-fuco (Hexfuco:chl $a=0.06$ ).

Gyroxanthin diester pigments were present in chloroplast Types 2 and 3 except in Takayama cf. helix (Table 4). In Karenia species, the pigment ratio of the major form (peak 45: GyrE $\mathrm{C}_{12: 0}$ ) was rather constant (GyrE:chl $a=0.11-0.17$ ); a more polar gyroxanthin-like compound (peak 43) was the second most abundant form (GyrE1-like:chl $a=0.01-$ 0.03). In Karlodinium species, GyrE $C_{12: 0}$ (peak 45) was also the major compound (GyrE:chl $a=$ $0.11-0.24)$, with variable contribution of the more retained GyrE C ${ }_{14: 0}$ (peak 46, GyrE:chl $a=0.02-0.09$ ).

Fucoxanthin was the major carotenoid in chloroplast Type 4 (0.52 to 0.75 ), while $\beta$, $\psi$-carotene could only be quantified in Kryptoperidinium foliaceum VGO556 (0.052). Pigment ratios in chloroplast Type 5 (Dinophysis spp.) were rather constant with Allo:chl a $=1.32-1.62$, Croco: $\mathrm{chl} a=0.05-0.08$ and $\beta \varepsilon-\operatorname{car}: \mathrm{chl} a$ $=0.15-0.20$.

Chloroplast Type 6, represented by 4 strains of Lepidodinium chlorophorum, showed marked differences in carotenoids and chl $b$ pigment ratios (Table 5). The North Sea strain (BAH100ME, the type culture) showed violaxanthin as the major carotenoid (Viola:chl $a=0.32$ ), with an unknown carotenoid (peak 46) as the second most important carotenoid (Unk car:chl $a=0.18$ ). In both British Channel (RCC1488, RCC1489) and Nervion River (Dino16 EUH) strains, the unknown carotenoid was the major carotenoid (Unk car:chl $a=0.14-0.17$ ), followed by violaxanthin (Viola:chl $a=0.08-0.32$ ). Lutein was detected as traces in the 4 strains. $\beta \varepsilon$-car was the major carotene in BAH100ME and Dino16EUH strains ( $\beta \varepsilon$ car:chla $=0.03-0.11$ ).

\section{Occurrence of pigment-based chloroplast types across dinoflagellate taxa}

The distribution patterns of pigment-based chloroplast types across dinoflagellate taxa are summarised in Table 6. These examples showed the different 
Table 3. Molar pigment ratios to chlorophyll (chl) a and their variability in chloroplast Type 1

\begin{tabular}{|c|c|c|c|c|c|c|c|}
\hline Order and species & Strain code & Peri:chl $C_{2}$ & Peri:chl a & Chl $C_{2}: \operatorname{chl~} a$ & Chl $c_{1}: \operatorname{chl} a$ & Diadino:chl a & Dino:chl a \\
\hline \multicolumn{8}{|l|}{ Gonyaulacales } \\
\hline Alexandrium affine & PA2V & 4.08 & 1.08 & 0.27 & 0.00 & 0.52 & 0.22 \\
\hline A. andersonii & CCMP1718 & 3.36 & 1.14 & 0.34 & 0.00 & 0.60 & 0.17 \\
\hline A. andersonii & VGO664 & 4.48 & 1.39 & 0.31 & 0.00 & 0.64 & 0.09 \\
\hline A. andersonii & SZN-12 & 3.19 & 0.61 & 0.19 & 0.00 & 0.41 & 0.18 \\
\hline A. catenella & AT02 & 3.05 & 0.85 & 0.28 & 0.00 & 0.63 & 0.24 \\
\hline A. catenella & VGO609 & 3.00 & 0.84 & 0.28 & 0.00 & 0.43 & 0.39 \\
\hline A. catenella & AL96 & 2.90 & 0.64 & 0.22 & 0.00 & 0.28 & 0.14 \\
\hline A. insuetum & ICMB218 & 3.16 & 1.02 & 0.32 & 0.00 & 0.38 & 0.11 \\
\hline A. margalefii & ICMB & 3.47 & 1.11 & 0.32 & 0.00 & 0.41 & 0.14 \\
\hline A. margalefii & VGO661 & 2.94 & 0.90 & 0.31 & 0.00 & 0.30 & 0.15 \\
\hline A.minutum & AL1V & 5.05 & 1.34 & 0.27 & 0.00 & 0.40 & 0.17 \\
\hline A. minutum & AMAD01 & 3.31 & 1.36 & 0.41 & 0.00 & 0.46 & 0.17 \\
\hline A. minutum & CLONE4 & 2.68 & 1.07 & 0.40 & 0.00 & 0.43 & 0.20 \\
\hline A. minutum & VGO577 & 3.14 & 1.11 & 0.35 & 0.00 & 0.47 & 0.16 \\
\hline A. ostenfeldii & AOTV-A1A & 3.29 & 0.98 & 0.30 & 0.02 & 0.84 & 0.20 \\
\hline A. ostenfeldii & AOTV-A4A & 3.04 & 0.89 & 0.29 & 0.01 & 0.80 & 0.16 \\
\hline A. peruvianum & AM10C & 4.94 & 1.24 & 0.25 & 0.00 & 0.63 & 0.14 \\
\hline A. pseudogonyaulax & VGO706 & 3.41 & 1.28 & 0.38 & 0.00 & 0.28 & 0.07 \\
\hline A. tamarense & CCMP1493 & 3.24 & 0.95 & 0.29 & 0.00 & 0.40 & 0.17 \\
\hline A. tamarense & MDQ1096 & 3.30 & 1.14 & 0.34 & 0.00 & 0.50 & 0.18 \\
\hline A. tamarense & PE1V & 2.81 & 0.95 & 0.34 & 0.00 & 0.38 & 0.16 \\
\hline A. tamarense & VGO553 & 3.59 & 1.11 & 0.31 & 0.00 & 0.44 & 0.16 \\
\hline A. tamutum & VGO617 & 3.30 & 1.21 & 0.37 & 0.00 & 0.59 & 0.17 \\
\hline A. taylori & AM8V & 2.16 & 0.55 & 0.27 & 0.00 & 0.67 & 0.25 \\
\hline A. taylori & VGO703 & 2.36 & 0.63 & 0.27 & 0.00 & 0.37 & 0.23 \\
\hline Coolia canariensis & VGO775 & 4.11 & 1.56 & 0.38 & 0.00 & 0.63 & 0.15 \\
\hline C. canariensis & VGO787 & 4.00 & 2.06 & 0.52 & 0.00 & 0.57 & 0.13 \\
\hline C. monotis & CM2V & 3.14 & 1.02 & 0.33 & 0.00 & 0.58 & 0.16 \\
\hline C. monotis & CM6V & 3.01 & 1.11 & 0.37 & 0.00 & 0.65 & 0.17 \\
\hline C. monotis & RIKZ4 & 2.49 & 1.08 & 0.43 & 0.00 & 0.59 & 0.18 \\
\hline C. monotis & CCMP1345 & 2.65 & 1.15 & 0.43 & 0.00 & 0.47 & 0.19 \\
\hline Coolia sp. & VG0923 & 3.00 & 1.05 & 0.35 & 0.00 & 0.42 & 0.13 \\
\hline C. tropicalis & CCMP1744 & 2.23 & 1.14 & 0.52 & 0.07 & 0.60 & 0.17 \\
\hline Fragilidium sp. & VGO692 & 3.05 & 0.96 & 0.31 & 0.00 & 0.68 & 0.19 \\
\hline Fragilidium sp. & IO 91-01 & 2.84 & 1.03 & 0.36 & 0.00 & 0.52 & 0.20 \\
\hline Gambierdiscus excentricus & VGO790 & 3.39 & 1.52 & 0.45 & 0.06 & 0.62 & 0.20 \\
\hline Gambierdiscus sp. & VGO920 & 2.72 & 0.91 & 0.33 & 0.04 & 0.53 & 0.18 \\
\hline Gambierdiscus sp. & KC81G1 & 2.72 & 1.10 & 0.41 & 0.07 & 0.62 & 0.16 \\
\hline Lingulodinium polyedrum & LP4V & 3.85 & 1.11 & 0.29 & 0.00 & 0.37 & 0.20 \\
\hline L. polyedrium & LP9V & 4.12 & 1.10 & 0.27 & 0.00 & 0.37 & 0.19 \\
\hline Neoceratium furca & Nfurca1 & 2.81 & 0.72 & 0.26 & 0.00 & 0.38 & 0.01 \\
\hline Ostreopsis ovata & OS01BR & 3.00 & 1.19 & 0.40 & 0.00 & 0.76 & 0.14 \\
\hline O. cf. ovata & VGO611 & 2.95 & 1.18 & 0.40 & 0.00 & 0.47 & 0.13 \\
\hline O. cf. siamensis & OS3V & 3.42 & 1.43 & 0.42 & 0.00 & 1.01 & 0.12 \\
\hline O. cf. siamensis & VGO613 & 3.49 & 1.37 & 0.39 & 0.00 & 0.74 & 0.14 \\
\hline O. cf. siamensis & VGO883 & 3.35 & 1.22 & 0.37 & 0.00 & 0.60 & 0.14 \\
\hline Protoceratium reticulatum & GG1AM & 2.84 & 1.02 & 0.36 & 0.01 & 0.40 & 0.16 \\
\hline P. reticulatum & CCMP404 & 3.88 & 0.94 & 0.24 & 0.04 & 0.62 & 0.19 \\
\hline$P$. reticulatum & CCMP1720 & 4.26 & 1.02 & 0.24 & 0.03 & 0.64 & 0.15 \\
\hline \multicolumn{8}{|l|}{ Gymnodiniales } \\
\hline Akashiwo sanguinea & VGO138 & 2.20 & 0.68 & 0.31 & 0.00 & 0.68 & 0.20 \\
\hline A. sanguinea & VGO626 & 2.91 & 0.75 & 0.25 & 0.00 & 0.41 & 0.20 \\
\hline Amphidinium carterae & A01BR & 2.04 & 1.17 & 0.57 & 0.00 & 0.90 & 0.10 \\
\hline A. carterae & ACMK03 & 1.60 & 0.87 & 0.54 & 0.00 & 0.77 & 0.19 \\
\hline A. carterae & ACRN02 & 1.81 & 1.09 & 0.60 & 0.00 & 0.70 & 0.07 \\
\hline A. cf. carterae & A1V & 2.29 & 0.94 & 0.41 & 0.00 & 0.56 & 0.09 \\
\hline Barrufeta bravensis & VGO859 & 1.85 & 0.61 & 0.34 & 0.00 & 0.75 & 0.18 \\
\hline B. bravensis & VGO860 & 1.93 & 0.79 & 0.41 & 0.00 & 0.81 & 0.42 \\
\hline B. bravensis & VGO864 & 1.92 & 0.54 & 0.29 & 0.00 & 0.89 & 0.32 \\
\hline Gymnodinium catenatum & GC11V & 2.40 & 0.72 & 0.30 & 0.00 & 0.62 & 0.28 \\
\hline
\end{tabular}


Table 3 (continued)

\begin{tabular}{|c|c|c|c|c|c|c|c|}
\hline Order and species & Strain code & Peri:chl $C_{2}$ & Peri:chl a & $\mathrm{Chl} C_{2}: \operatorname{chl~a}$ & Chl $c_{1}: \operatorname{chl~a}$ & Diadino:chl a & Dino:chl a \\
\hline G. catenatum & GC31AM & 1.93 & 0.58 & 0.30 & 0.00 & 0.51 & 0.28 \\
\hline G. catenatum & CS-302 & 1.84 & 0.82 & 0.44 & 0.00 & 0.64 & 0.24 \\
\hline G. impudicum & GY1VA & 1.94 & 0.66 & 0.35 & 0.00 & 0.59 & 0.29 \\
\hline G. instriatum & VGO642 & 2.51 & 0.84 & 0.34 & 0.00 & 0.73 & 0.15 \\
\hline G. cf. microreticulatum & VGO581 & 1.93 & 0.59 & 0.30 & 0.02 & 0.55 & 0.20 \\
\hline G. nolleri & DK5 & 2.89 & 1.02 & 0.35 & 0.00 & 0.42 & 0.32 \\
\hline Gyrodinium uncatenum & CS289-3 & 2.54 & 0.71 & 0.28 & 0.41 & 0.75 & 0.12 \\
\hline \multicolumn{8}{|l|}{ Peridiniales } \\
\hline Heterocapsa niei & VGO399 & 1.39 & 0.79 & 0.56 & 0.12 & 0.52 & 0.18 \\
\hline H. triquetra & VGO1053 & 1.40 & 0.70 & 0.50 & 0.00 & 0.73 & 0.16 \\
\hline Peridinium aciculiferum & PAER-1 & 2.62 & 0.81 & 0.31 & 0.14 & 0.43 & 0.10 \\
\hline$P$. aciculiferum & PAER-2 & 2.75 & 0.88 & 0.32 & 0.16 & 0.44 & 0.10 \\
\hline Scrippsiella hangoei & STHV-1 & 1.95 & 0.89 & 0.45 & 0.02 & 0.51 & 0.11 \\
\hline S. hangoei & STHV-2 & 1.94 & 0.92 & 0.46 & 0.02 & 0.53 & 0.10 \\
\hline S. hangoei & STHV-5 & 2.04 & 0.81 & 0.38 & 0.02 & 0.44 & 0.09 \\
\hline S. hangoei & STHV-6 & 1.96 & 0.85 & 0.43 & 0.03 & 0.52 & 0.11 \\
\hline Scrippsiella sp. & S3V & 4.87 & 1.18 & 0.24 & 0.00 & 0.54 & 0.10 \\
\hline \multicolumn{8}{|l|}{ Prorocentrales } \\
\hline Prorocentrum arenarium & VGO776 & 7.17 & 0.95 & 0.13 & 0.03 & 0.59 & 0.27 \\
\hline P. belizeanum & PBMA01 & 19.11 & 1.65 & 0.09 & 0.00 & 0.80 & 0.25 \\
\hline P. belizeanum & VGO867 & 24.54 & 1.43 & 0.06 & 0.01 & 0.75 & 0.22 \\
\hline P. compressum & VGO621 & 4.59 & 1.17 & 0.26 & 0.00 & 0.45 & 0.12 \\
\hline P. cf. faustiae & VGO894 & 7.13 & 1.16 & 0.16 & 0.00 & 0.50 & 0.26 \\
\hline P. levis & VGO777 & 38.92 & 1.20 & 0.03 & 0.01 & 0.62 & 0.24 \\
\hline P. levis & VG0957 & 15.04 & 0.97 & 0.07 & 0.00 & 0.61 & 0.30 \\
\hline P. lima & PL2V & 11.66 & 1.54 & 0.13 & 0.00 & 1.09 & 0.30 \\
\hline P. cf. lima & VGO620 & 3.68 & 1.32 & 0.36 & 0.01 & 0.82 & 0.30 \\
\hline P. micans & PM1V & 7.66 & 1.24 & 0.16 & 0.00 & 0.62 & 0.13 \\
\hline P. minimum & VGO365 & 4.59 & 1.21 & 0.27 & 0.00 & 0.53 & 0.07 \\
\hline P. minimum & VGO367 & 10.31 & 1.65 & 0.16 & 0.00 & 0.43 & 0.08 \\
\hline P. nux & UTEX1008 & 3.51 & 1.51 & 0.43 & 0.00 & 0.73 & 0.11 \\
\hline P. rathymum & VG0893 & 9.94 & 1.59 & 0.16 & 0.00 & 0.64 & 0.16 \\
\hline P. rostratum & PR1V & 18.00 & 1.69 & 0.09 & 0.00 & 0.46 & 0.12 \\
\hline P. triestinum & PT2V & 4.13 & 1.35 & 0.33 & 0.00 & 0.64 & 0.14 \\
\hline \multicolumn{8}{|l|}{ Thoracosphaerales } \\
\hline Thoracosphaera heimii & CCMP1069 & 2.35 & 1.13 & 0.48 & 0.00 & 0.89 & 0.05 \\
\hline Mean & & 4.57 & 1.07 & 0.33 & 0.01 & 0.57 & 0.18 \\
\hline SD & & 5.35 & 0.29 & 0.12 & 0.02 & 0.16 & 0.07 \\
\hline $\mathrm{N}$ & & 90 & 90 & 90 & 21 & 90 & 90 \\
\hline
\end{tabular}

specificity of the chloroplast types across Dinophyta. All orders, except Dinophysiales, include some genera with chloroplast Type 1 chloroplast. Besides representatives of Type 1, Gymnodiniales include other genera of chloroplast Types 2, 3 and 6. Finally, the order Peridiniales encompasses representatives of pigment Type 4 as well as the already mentioned Type 1.

Three chloroplast types contain a single genus (Type 2 associated with Karenia, Type 5 with Dinophysis and Type 6 with Lepidodinium), while Type 3 is linked to 2 genera (Karlodinium and Takayama), and Type 4 is confined to 3 genera (Durinskia, Galeidinium and Kryptoperidinium).

\section{DISCUSSION}

\section{Comparison with previous surveys of Dinophyta}

The first comprehensive study of chloroplast pigments in dinoflagellates used thin layer chromatography to describe the chlorophyll and carotenoid composition of 22 species belonging to the orders Gymnodiniales, Gonyaulacales, Peridiniales and Prorocentrales (Jeffrey et al. 1975). Peridinin was the major carotenoid in 19 of the species, while fucoxanthin was the major carotenoid in 3 peridinin-lacking Peridiniales. Since then, dinoflagel- 
Table 4. Molar pigment ratios (accessory chl:chl a) in chloroplast Types 2 and 3. MGDG-chl c:monogalactosyl-diacylglycerol-chl $C$ compounds. (-): pigments not found

\begin{tabular}{|c|c|c|c|c|c|c|c|c|c|c|c|c|c|c|c|c|c|}
\hline Species and strain code & 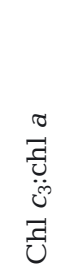 & 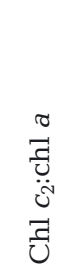 & 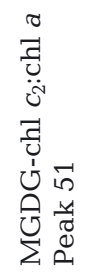 & 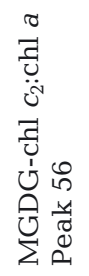 & 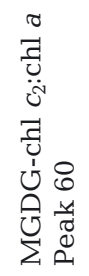 & 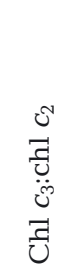 & 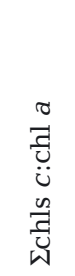 & 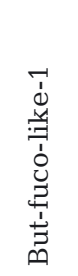 & 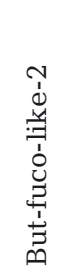 & 䓪 & $\underset{\text { 吕 }}{\stackrel{O}{Z}}$ & 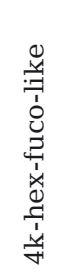 & 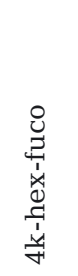 & 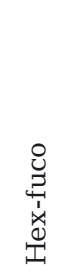 & 齐 & 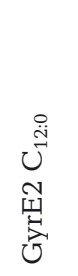 & 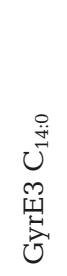 \\
\hline \multicolumn{18}{|l|}{ Chloroplast Type 2} \\
\hline Karenia brevis CCMP718 & 0.07 & 0.12 & - & 0.005 & - & 0.58 & 0.20 & 0.04 & 0.07 & 0.08 & 0.34 & 0.05 & 0.11 & 0.07 & - & 0.11 & - \\
\hline K. brevis CCMP2281 & 0.07 & 0.15 & - & 0.004 & - & 0.47 & 0.22 & 0.06 & 0.06 & 0.08 & 0.24 & 0.09 & 0.10 & 0.09 & - & 0.14 & - \\
\hline K. mikimotoi CCMP429 & 0.08 & 0.16 & - & 0.002 & - & 0.47 & 0.24 & 0.07 & 0.07 & 0.10 & 0.33 & 0.11 & 0.11 & 0.09 & 0.02 & 0.11 & - \\
\hline K. papilonacea VGO679 & 0.05 & 0.13 & - & 0.005 & - & 0.44 & 0.19 & 0.02 & 0.04 & 0.13 & 0.14 & 0.09 & 0.09 & 0.29 & 0.03 & 0.17 & 0.01 \\
\hline K. selliformis VGO875 & 0.08 & 0.16 & - & 0.003 & - & 0.51 & 0.24 & 0.08 & 0.09 & 0.08 & 0.27 & 0.10 & 0.12 & 0.08 & 0.01 & 0.12 & 0.01 \\
\hline K. umbella Gy2DE & 0.07 & 0.16 & - & 0.002 & - & 0.58 & 0.23 & 0.01 & 0.01 & 0.13 & 0.27 & 0.10 & 0.08 & 0.32 & - & 0.16 & - \\
\hline \multicolumn{18}{|l|}{ Chloroplast Type 3} \\
\hline Karlodinium armiger GC-7 & 0.08 & 0.15 & 0.010 & 0.010 & 0.002 & 0.55 & 0.25 & - & - & 0.01 & 0.34 & - & - & 0.45 & - & 0.11 & 0.05 \\
\hline K. decipiens Nervión34 & 0.07 & 0.22 & - & 0.002 & - & 0.33 & 0.29 & - & - & 0.25 & 0.22 & - & - & 0.44 & - & 0.14 & 0.09 \\
\hline K. veneficum CCMP415 & 0.08 & 0.22 & - & - & - & 0.38 & 0.30 & - & - & 0.13 & 0.56 & - & - & 0.31 & - & 0.24 & 0.02 \\
\hline K. veneficum CCMP1974 & 0.08 & 0.22 & - & - & - & 0.35 & 0.30 & - & - & 0.16 & 0.44 & - & - & 0.28 & - & 0.16 & 0.09 \\
\hline K. veneficum CS-310 & 0.10 & 0.23 & - & - & - & 0.38 & 0.33 & - & - & 0.18 & 0.75 & - & - & 0.33 & - & 0.20 & 0.04 \\
\hline K. veneficum GC-4 & 0.06 & 0.18 & - & - & - & 0.29 & 0.30 & - & - & 0.08 & 0.72 & - & - & 0.21 & - & 0.19 & 0.04 \\
\hline K. veneficum VGO691 & 0.07 & 0.19 & - & - & - & 0.38 & 0.26 & - & - & 0.10 & 0.58 & - & - & 0.25 & - & 0.20 & 0.03 \\
\hline K. veneficum VGO870 & 0.07 & 0.21 & - & - & - & 0.31 & 0.28 & - & - & 0.19 & 0.30 & - & - & 0.39 & - & 0.20 & 0.02 \\
\hline Takayama cf. helix VGO341 & 0.07 & 0.21 & 0.005 & 0.013 & 0.007 & 0.33 & 0.31 & - & - & - & 1.18 & - & - & 0.06 & - & - & - \\
\hline
\end{tabular}

Table 5. Molar pigment ratios to chlorophyll (chl) $a$ in chloroplast Types 4, 5 and 6. tr.: trace amounts; other abbreviations as in Table 1

\begin{tabular}{|c|c|c|c|c|c|c|c|c|}
\hline Chloroplast Type 4 & $\mathrm{Chl} C_{2}$ & Chl $c_{1}$-like $E g$ & MgDVP & Chl $C_{1}$ & Fuco & $\beta \psi$-car & & \\
\hline Peridinium balticum CS-33 & 0.04 & 0.005 & - & 0.09 & 0.54 & tr. & & \\
\hline Kryptoperidinium foliaceum CS-37 & 0.06 & 0.009 & 0.002 & 0.11 & 0.52 & tr. & & \\
\hline K. foliaceum VGO556 & 0.08 & 0.01 & 0.004 & 0.11 & 0.75 & 0.05 & & \\
\hline Chloroplast Type 5 & $\mathrm{Chl} C_{2}$ & Alloxanthin & Crocoxanthin & $\beta \varepsilon$-car & & & & \\
\hline Dinophysis acuminata VGO1063 & 0.07 & 1.62 & 0.08 & 0.20 & & & & \\
\hline D. acuta VGO1065 & 0.09 & 1.35 & 0.07 & 0.18 & & & & \\
\hline D. caudata VGO1064 & 0.07 & 1.38 & 0.05 & 0.19 & & & & \\
\hline D. tripos VGO1062 & 0.09 & 1.32 & 0.05 & 0.15 & & & & \\
\hline Chloroplast Type 6 & $\mathrm{Neo}$ & Viola & Anth & Zea & Unk-car443-Lc & $\beta \varepsilon$-car & $\beta \beta$-car & Chl $b$ \\
\hline Lepidodinium chlorophorum Dino16EUH & 0.09 & 0.08 & 0.01 & 0.01 & 0.17 & 0.04 & 0.04 & 0.73 \\
\hline L. chlorophorum RCC1488 & 0.14 & 0.16 & 0.01 & 0.05 & 0.16 & 0.03 & 0.05 & 0.56 \\
\hline L. chlorophorum RCC1489 & 0.14 & 0.12 & 0.02 & 0.06 & 0.14 & 0.03 & 0.05 & 0.57 \\
\hline L. chlorophorum BAH100ME & 0.09 & 0.32 & 0.03 & 0.02 & 0.18 & 0.11 & 0.05 & 0.08 \\
\hline
\end{tabular}

lates with other pigment composition have been reported (chl $b$, Watanabe et al. 1990; alloxanthin, Meyer-Harms \& Pollehne 1998; acyloxyfucoxanthins, Bjørnland \& Tangen 1979, Tengs et al. 2000).

We applied HPLC to review the pigment composition of dinoflagellates belonging to 6 orders of the division Dinophyta (Table S1). Members of the Gonyaulacales, Prorocentrales and Thoracosphaerales analysed contained exclusively the peridinin-con- taining chloroplast Type 1 (Table 6), which included around two-thirds of the studied species.

Recently, an exception to the common chloroplast Type 1 distribution in Gonyaulacales was observed in Amylax buxus and A. triacantha, where anucleated cryptophyte vestiges (probably Teleaulax-related) were detected (Koike \& Takishita 2008). The order Dinophysiales comprises mostly heterotrophic dinoflagellates with only a reduced number of autotrophic species belonging to the genus Dinophysis. In 
Table 6. Distribution ( ) of pigment-based chloroplast types across Dinophyta taxa (class Dinophyceae)

\begin{tabular}{|c|c|c|c|c|c|c|}
\hline \multirow[t]{2}{*}{ Representative species } & \multicolumn{6}{|c|}{ Chloroplast type } \\
\hline & 1 & 2 & 3 & 4 & 5 & 6 \\
\hline \multicolumn{7}{|l|}{ Dinophysiales } \\
\hline Dinophysis acuminata & - & - & - & - & - & - \\
\hline \multicolumn{7}{|l|}{ Gonyaulacales } \\
\hline Alexandrium minutum & - & - & - & - & - & - \\
\hline \multicolumn{7}{|l|}{ Gymnodiniales } \\
\hline Gymnodinium catenatum & - & - & - & - & - & - \\
\hline Karenia mikimotoi & - & ○ & - & - & - & - \\
\hline Karlodinium veneficum & - & - & - & - & - & - \\
\hline Takayama cf. helix & - & - & $\bullet$ & - & - & - \\
\hline Lepidodinium chlorophorum & - & - & - & - & - & 0 \\
\hline \multicolumn{7}{|l|}{ Peridiniales } \\
\hline Heterocapsa sp. & $\bullet$ & - & - & - & - & - \\
\hline Durinskia baltica & - & - & - & - & - & - \\
\hline Galeidinium rugatum $^{\mathrm{a}}$ & - & - & - & - & - & - \\
\hline Kryptoperidinium foliaceum & - & - & - & ○ & - & - \\
\hline \multicolumn{7}{|l|}{ Prorocentrales } \\
\hline Prorocentrum lima & ○ & - & - & - & - & - \\
\hline \multicolumn{7}{|l|}{ Thoracosphaerales } \\
\hline Thoracosphaera heimii & - & - & - & - & - & - \\
\hline${ }^{\mathrm{a} F r o m ~ T a m u r a ~ e t ~ a l . ~(2005) ~}$ & & & & & & \\
\hline
\end{tabular}

this case, the cryptophyte chloroplast Type 5 was present, although the presence of a haptophyte-type plastid in D. mitra has been claimed (Koike et al. 2005). Such an important exception should be supported by evidence from HPLC pigment analysis, which has not been yet performed. Peridinincontaining species have never been reported in Dinophysiales. The order Peridiniales includes both peridinin-containing chloroplast Type 1 and the fucoxanthin-containing Type 4. The major pigmentbased chloroplast diversity was observed in the Gymnodiniales, with 4 out of 6 chloroplast types defined here (Types 1, 2, 3 and 6). In addition, a few Gymnodiniales species have been reported to harbour endosymbiotic algae belonging to chloroplast Type 4 (Gymnodinium quadrilobatum, Horiguchi \& Pienaar 1994) and Type 5 (Amphidinium latum, Horiguchi \& Pienaar 1992) chloroplasts, but pigment analyses were not detailed in these studies. These findings support the description of Gymnodiniales as a heterogeneous order, as previously indicated by Saldarriaga et al. (2001)

\section{Pigment-based chloroplast types and dinophyte phylogeny}

Pigmentary groups in phytoplankton have been traditionally based on the occurrence of certain marker pigments (Jeffrey et al. 1999). However, in the present study we defined pigment-based chloroplast types to illustrate the fact that dinoflagellates include not only secondary but also tertiary plastids from different algal lineages. Dinoflagellates have acquired and lost their chloroplasts multiple times during their evolutionary history. The ability to acquire and maintain other eukaryotic plastids has led to the diversity of dinoflagellate plastids (Koike et al. 2005). Peridinin-pigmented dinoflagellates contain secondary plastids that appear to have undergone more plastid genome reduction than other eukaryotes. It is generally accepted that peridinincontaining dinoflagellate plastids are derived from red algae (Zhang et al. 1999), but whether they are secondary plastids equivalent to plastids of stramenopiles, haptophytes or cryptophytes, or they are tertiary plastids derived from one of the other secondary plastids, has not yet been completely resolved (Wang et al. 2008). The number of endosymbiotic events in dinoflagellates probably exceeds those in other known eukaryotes (Takishita et al. 2002).

Saldarriaga et al. (2004) proposed a scheme of the evolutionary history of dinoflagellates based on molecular trees of concatenated nuclear genes, morphological and palaeontological information. If we superimpose the pigment-based chloroplast types on that scheme (Fig. 3), it appears that most of the pigment diversity in dinoflagellates occurs in a certain group of dinoflagellate orders (Peridiniales, Dinophysiales, Gymnodiniales, Thoracosphaerales) sharing a common ancestor.

Peridiniales occupy a central position in the evolution of dinoflagellates and probably gave rise to other thecate taxa and also to Thoracosphaerales and Blastodiniales. Montresor et al. (2003) reported that Suessiales contain peridinin. Karenia and Karlodinium occupy an early divergent branch in many molecular studies and would also represent the first deviation of the chloroplast Type 1 (peridinin) among dinoflagellates.

\section{Tertiary plastids in dinoflagellates}

Karenia: chloroplast Type 2

Chloroplast Type 2 are considered tertiary plastids related to Type 7 haptophytes (Zapata et al. 2004): both contain chl $C_{2}, C_{3}$ and MGDG-chl $C_{2}$ [14:0/14:0] Chrysochromulina-type. However, the carotenoid composition of Karenia species detected in our study does not match any of the haptophyte pigment types 
(1?) Phytodiniales

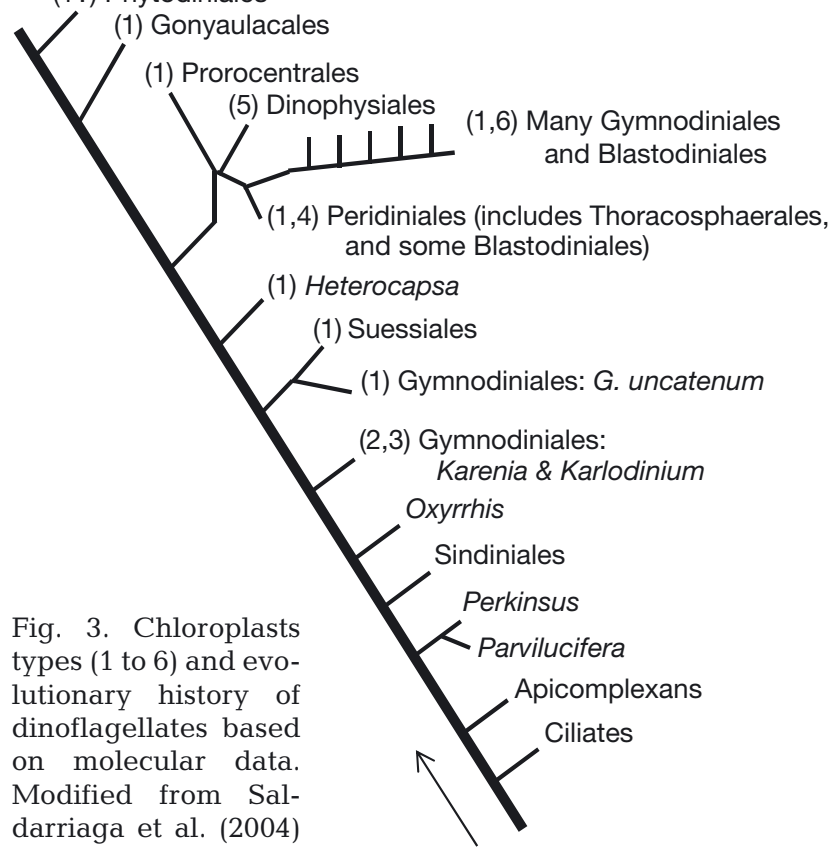

described to date. In addition to Fuco, Hex-fuco and 4-keto-hex-fuco, 3 novel pigments were detected. One of these (peak 15) was tentatively identified as 4-keto-but-fuco; the other 2 pigments (peaks 13 and 22) shared both absorption spectra with the above mentioned 4-keto forms (Garrido et al. unpubl.). Pigment Type 2 embraces well-known HAB species belonging to the genera Karenia (i.e. K. brevis, $K$. mikimotoi, $K$ selliformis). It is noteworthy that the particular fingerprint profile of Karenia species could be useful to detect their presence in monitoring programmes (Garrido et al. unpubl.).

Gyroxanthin diester was considered a marker pigment for Karlodinium veneficum (= Gymnodinium galatheanum) (see Bjørnland et al. 2000) and also for Karenia brevis (Bjørnland et al. 2003). However, a pigment with similar chromatographic properties has also been detected in the pelagophyceans Pelagomonas calceolata (Bjørnland et al. 2003), and tentatively in Aureococcus anophageferens, Pelagococcus subviridis (Zapata 2005) and several haptophytes (Zapata 2005). The occurrence of gyroxanthin in Karlodinium and Karenia is noticeable for its quantitative relevance, but it is not taxon specific (Garcés et al. 2006). The genus Karenia currently embraces 13 species (Guiry \& Guiry 2010). Thus, the homogeneity in the pigment composition observed in the 4 species analysed here should be confirmed by the analysis of 9 additional species whose original or further description (see Table S5 in the supplement) did not include pigment data.
Karlodinium and Takayama: chloroplast Type 3

Chloroplast Type 3 lacks keto forms of acyloxyfucoxanthin-derivatives, and the occurrence of both MGDG-chl $C_{2}$ and gyroxanthin diester is not a general trait. Pigment Type 3 groups the well-known HAB species Karlodinium veneficum (= K. micrum, Gymnodinium galatheanum). The genus Karlodinium currently includes 10 species (de Salas et al. 2008); however, the pigment composition of 5 of them has not yet been analysed (see Table S5). HPLC pigment analysis of $K$. australe (de Salas et al. 2005) indicates that this species contains Fuco and Hexfuco as the main carotenoid pigments, with But-fuco present in trace amounts. $K$. australe did not produce gyroxanthin-diester, a pigment typical of $K$. veneficum (K. micrum, Bjørnland et al. 2000) and Karenia species (de Salas et al. 2004).

In a recent study, Bachvaroff et al. (2009) analysed pigment variability between Karlodinium veneficum strains and detected 2 GyrE compounds sharing its absorption spectra and molecular weight. They were noted as GyrE and cis GyrE isomers, not as esters with different fatty acid residues.

The marine dinoflagellate genus Takayama currently comprises 6 species (Table S5). Takayama cf. helix (VGO-341) contains an MGDG-chl $c_{2}$ pigment previously detected in Emiliania huxleyi (peak 53) and a second one also detected in Prymnesium faveolatum (peak 60). A different pigment profile was observed in T. tasmanica, which contains a GyrE-like pigment more polar than that detected in Karenia umbella (de Salas et al. 2004). In addition, T. tasmanica and $T$. cf. helix contain an MGDG-chl $c_{2}$, closely eluting to zeaxanthin, also detected in Haptolina (= Chrysochromulina) hirta and other Chrysochromulina species (Zapata et al. 2001, Seoane et al. 2009) recently reasigned to the new genus Haptolina (Edvardsen et al. 2011). However, the 2 Takayama species differ in that the occurrence of GyrE is restricted to $T$. tasmanica, and Hex-fuco is only detected in T. cf. helix (de Salas et al. 2003). The other 4 Takayama species have not yet been analysed for pigment composition: T. acrotrocha, $T$. cladochroma, T. pulchella (de Salas et al. 2003) and T. tuberculata (de Salas et al. 2008).

Durinskia and Kryptoperidinium: chloroplast Type 4

The dinoflagellate species included in this chloroplast type correspond with those described as bearing diatom endosymbionts: Durinskia baltica (= Peri- 
dinium balticum) (Withers et al. 1977, Carty \& Cox 1986) and Kryptoperidinium foliaceum (Jeffrey \& Vesk 1976, Kite et al. 1988). Chl $C_{1}$ is the dominant chl $C$ pigment in $K$. foliaceum and D. baltica; such a feature is also characteristic of Pavlova spp. (Van Lenning et al. 2003, Zapata et al. 2004), but it is unusual in diatoms (Stauber \& Jeffrey 1988).

In addition to fucoxanthin and $\mathrm{chl} c_{1}$ and $c_{2}$, Type 4 dinoflagellates contain minor $\mathrm{chl} c$-like pigments first detected, respectively, in the pavlovophyceans Pavlova gyrans (Fawley 1989) and Exanthemachrysis gayraliae (Van Lenning et al. 2003). These pigments also occur in several chrysophytes (e.g. synurophyceans and chrysophyceans; Zapata 2005, Jeffrey \& Wright 2006). Previous HPLC analysis of Kryptoperidinium foliaceum (Kempton et al. 2002, McEwan \& Keeling 2004) did not detect these pigments. The presence of $\beta, \psi$-carotene in K. foliaceum and Durinskia baltica is a singular feature with no correspondence in Bacillariophyceae and pavlovophyceans (haptophyte pigment Type 2). However, $\beta \psi$-car is a light-sensitive pigment, so its potential role as marker pigment is restricted to high light environments. Molecular analyses have traced the chloroplast origin of Peridinium balticum ( $=D$. baltica) and $K$. foliaceum to a pennate diatom (Chesnick et al. 1997).

According to Imanian et al. (2010), the endosymbiont in these dinoflagellate species would be closely related to the pennate diatom genus Nitzschia. However, Kryptoperidinium foliaceum seems to have incorporated 2 exogenous plasmids. These authors proposed the term 'dinotom' to refer to the complex cell derived from this tertiary endosymbiosis. The nature of the endosymbiont is similar in Durinskia cappensis (Pienaar et al. 2007). In the dinoflagellates Galeidinium rugatum (Tamura et al. 2005) and Peridinium quinquecorne (Horiguchi \& Takano 2006), the diatom plastid seems to be from a centric diatom (Takano et al. 2008) obtained by serial replacement of diatom endosymbionts. Whether this different chloroplast (centric versus pennate diatom) source is reflected in the pigment composition of G. rugatum and $P$. quinquecorne is still under debate.

\section{Dinophysis: chloroplast Type 5}

The genus Dinophysis includes both photosynthetic and non-photosynthetic (heterotrophic) species, and the former are known to possess cryptophytetype plastids that contain the phycobilin pigment phycoerythrin (Vesk et al. 1996, Hewes et al. 1998, Hackett et al. 2003).
The origin of the Dinophysis spp. chloroplast was traced to Teleaulax amphioxeia (Janson 2004) and closely related to Geminiphera cryophyla in Dinophysis spp. from the Greenland Sea (Janson 2004, Minnhagen \& Janson 2006). Most species belonging to the genus Dinophysis harbour chloroplasts of cryptophyte origin. Whether these chloroplasts are temporarily sequestered from the prey (kleptoplastids) or permanent is controversial. Considering both molecular and ultrastructural evidence, Garcia-Cuetos et al. (2010) indicated that the plastids in D. acuminata are permanent and originate from Teleaulax or another closely related cryptophyte genus. Koike et al. (2005) suggested the presence of a haptophytetype plastid in D. mitra, although HPLC pigment data were not reported. If this is confirmed, it would be the first case of an armoured dinoflagellate containing a haptophyte-type chloroplast. The difficulty in culturing Dinophysis was a bottleneck for many decades to advance in basic studies of its biology (Park et al. 2006). At present, distinct species of Dinophysis have been cultured by different laboratories (D. acuminata: Park et al. 2006; D. fortii: Nagai et al. 2008 ; D. caudata: Nishitani et al. 2008a; D. infundibulus: Nishitani et al. 2008b; D. tripos: Rodríguez et al. 2012). However, our study represents the first HPLC pigment data from cultured Dinophysis species.

\section{Lepidodinium chlorophorum: chloroplast Type 6}

The genus Lepidodinium was recently revised (Hansen et al. 2007), and the previously named Gymnodinium chlorophorum was renamed as $L$. chlorophorum. The extant plastid in the dinoflagellate $L$. viride is most probably acquired by plastid replacement via tertiary endosymbiosis (reviewed by Delwiche 2007). This dinoflagellate possesses a green-pigmented plastid surrounded by 4 membranes. First evidence of pigment composition (W. W. C Gieskes pers. comm. to Elbrächter \& Schnepf 1996) pointed out the presence of prasinoxanthin; as a consequence, the prasinophyte-origin of the chloroplast was assumed. Recent results indicate that the green plastids in Lepidodinium are derived from an alga belonging to core chlorophytes (Minge et al. 2010, Matsumoto et al. 2011), distinct from the ancient prasinophyceans. Our results show clearly that $L$. chlorophorum lacks prasinoxanthin. Moreover, the results obtained (see Table 2) also differ from other pigment patterns so far observed within the prasinophycean algae (Egeland et al. 1995, Latasa et al. 2004, Yoshii 2006, Garrido et al. 2009). The absence 
(or traces) of lutein is noticeable, as is the occurrence of an unknown carotenoid (peak 42) with similar retention time as lutein in the HPLC system employed. Both differences in the UV-vis spectrum (Table 1) and chromatographic retention using a different HPLC method (Garrido et al. 2009) allowed distinction of the unknown pigment from lutein and other major pigments detected in Chlorophyta. The structural elucidation of this carotenoid (peak 42) is currently under investigation (Zapata et al. unpubl.).

\section{Implications of dinoflagellate chloroplast types in biological oceanography and chemotaxonomy}

The use of HPLC pigment analysis for inferring phytoplankton assemblages through marker pigments increased the interest for phytoplankton pigments in oceanography (revised by Jeffrey et al. 1997, 1999, Jeffrey \& Wright 2006). The use of peridinin to map the contribution of dinoflagellates to total chl $a$ is generally accepted due to the prevalence of peridinin-containing chloroplasts in photoautotrophic dinoflagellates. In fact, our study seems to validate this general approach, as peridinin was the characteristic marker pigment in two-thirds of the analysed species. However, this approach is prone to error if a single pigment algorithm is employed. For example, the contribution of dinoflagellates to total chl a has usually been obtained by using a fixed equation: [chl a] DINO = 1.5 [Peri] obtained from a single Amphidinium sp. isolate (see Letelier et al. 1993), which corresponds to Peri:chl a ratios of 0.67 (mass ratio) or 0.65 (molar ratio, where molar ratio is $\mathrm{MW}$ chl a:MW Peri $=0.97 \times$ mass ratio). The contribution of dinoflagellates to total chl a assuming such a fixed factor will produce either an overestimation or subestimation, assuming the Peri:chl a range obtained in the present paper (0.54-2.06 molar ratio, Table 3). This range for Peri:chl a ratios agrees well with that obtained in field studies using the chemical taxonomy programme CHEMTAX (from 0.52 to 1.51, Table S6). CHEMTAX (see Mackey et al. 1996) has demonstrated its capacity for reconstructing phytoplankton assemblages from HPLC pigment data (Wright et al. 1996, Mackey et al. 1998, Higgins \& Mackey 2000, Wright \& van den Enden 2000, Rodríguez et al. 2003). This program relies upon (1) general information of major algal groups present in the study area and (2) an initial pigment to chl a ratio matrix basically obtained from the literature for relevant phytoplankton groups ('algal classes'), or even user-defined 'algal pigment classes' (Rodríguez et al.
2003). In this sense, the values shown in Tables 3 to 5 represent improved pigment ratios and define new 'chemotaxonomic categories' (i.e. 'Dinos Types 1 to 6') which may be incorporated into CHEMTAX analysis.

The use of peridinin as a single marker pigment for dinoflagellates ignores the potential contribution of species from chloroplast Types 2 to 6 , whose contribution to chl a would be assigned to other algal groups with similar pigment composition (Table S7). For example, the contribution of Hex-fuco-containing dinoflagellates to total chl a might be underestimated due to the presence of haptophytes sharing similar pigment composition. Some bloom-forming dinoflagellates (Karenia brevis, K. mikimotoi, Karlodinium veneficum) share several pigment markers with bloom-forming haptophytes (Chrysochromulina spp., Emiliania huxleyi, Phaeocystis spp.), but the specificity of chloroplast Type 2 allows us to discriminate Karenia species from Hex-fuco-containing haptophytes. Comparing molar pigment ratios of haptophytes from pigmentary groups 6,7 and 8 (sensu Zapata et al. 2004) with Hex-fuco-containing dinoflagellates, the values chl $c_{3}: \operatorname{chl} a_{1} \operatorname{chl~} c_{2}: \operatorname{chl} a_{1} \operatorname{chl} c_{3}: \operatorname{chl}$ $C_{2}$ and total chl $c$ :total fuco are consistently higher in haptophytes relative to dinoflagellates of Types 2 and 3 (see Tables 3 \& 5 in Zapata et al. 2004). The index MGDG-chl $C_{2}$ :chl $a$ in Type 2 and 3 dinoflagellates is an order of magnitude lower than the values obtained within Types 6, 7 and 8 haptophytes (see Zapata et al. 2001, 2004, Seoane et al. 2009).

Type 4 dinoflagellates show a pigment profile closely related to some diatoms (Zapata 2005) and pavlovophyceans Type 2 (e.g. Pavlova gyrans: chl $c_{2}$ like $P$. gyrans type). In addition, Durinskia baltica and Kryptoperidinium foliaceum contain $\beta \psi$-car, which was claimed as the differential pigment in $K$. foliaceum (Kempton et al. 2002). However, $\beta \psi$-car contents have been shown to be dependent on light intensity in Tetraselmis suecica (Garrido et al. 2009), so the marker quality of this pigment in other species needs confirmation under different light regimes. Type 5 dinoflagellates share the pigment profile with autotrophic cryptophytes. In consequence, it is not possible to discriminate both algal groups in natural samples. The occurrence of green dinoflagellates is easily detected by pigment analysis, as both the presence of chl $b$ and the singular carotenoid profile are very characteristic. No other chl $b$-containing organism with similar pigment signature has been reported to date.

The importance of dinoflagellates in the picophytoplankton fraction, which have not been cultured yet, has been shown. For example, Latasa \& Bidigare 
(1998) found that often more than $50 \%$ (and up to $75 \%$ ) of peridinin appeared in the $<2 \mu \mathrm{m}$ fraction, whereas on the basis of peridinin concentration, Wright et al. (2009) estimated that dinoflagellates accounted for 0 to $11 \%$ of picoplanktonic chl $a$ in Antarctic waters. In addition, molecular sequences from many unknown dinoflagellates have been retrieved in open ocean samples (Moon-van der Staay et al. 2001, Lin et al. 2006). All of these facts underscore the necessity to isolate and cultivate new species of small dinoflagellates so that their pigment composition can be characterized, to advance our knowledge about the diversity of photosynthetic dinoflagellates in natural samples.

Acknowledgements. This work was supported by funds from the Xunta de Galicia, Spain (PGIDIT-06PXIB6021 43PR), from the Spanish Ministry of Science and Innovation (CSIC (200930I009) and from Instituto Español de Oceanografía (project CCIEO). This manuscript is a contribution from the Unidad Asociada IEO/CSIC 'Fitoplancton Tóxico'. We thank E. Campaña and N. Sanz for HPLC pigment analyses and I. Ramilo and A. Fernández-Villamarín for technical assistance with algal cultures.

\section{LITERATURE CITED}

Bachvaroff TR, Adolf JE, Place AR (2009) Strain variation in Karlodinium veneficum (Dinophyceae): toxin profiles, pigments, and growth characteristics. J Phycol 45: 137-153

Bjørnland T (1990) Chromatographic separation and spectrometric characterization of native carotenoids from the marine dinoflagellate Thoracosphaera heimii. Biochem Syst Ecol 18:307-316

Bjørnland T, Tangen K (1979) Pigmentation and morphology of a marine Gyrodinium (Dinophyceae) with a major carotenoid different from peridinin and fucoxanthin. J Phycol 15:457-463

Bjørnland T, Fiksdahl A, Skjetne T, Krane J, Liaaen-Jensen S (2000) Gyroxanthin - the first allenic acetylenic carotenoid. Tetrahedron 56:9047-9056

> Bjørnland T, Haxo FT, Liaaen-Jensen S (2003) Carotenoids of the Florida red tide Karenia brevis. Biochem Syst Ecol 31:1147-1162

> Blackburn SI, Hallegraeff GM, Bolch CJ (1989) Vegetative reproduction and sexual life cycle of the toxic dinoflagellate Gymnodinium catenatum from Tasmania, Australia. J Phycol 25:577-590

Bolch CJS, Negri AP, Hallegraeff GM (1999) Gymnodinium microreticulatum sp. nov. (Dinophyceae): a naked, microreticulate cyst-producing dinoflagellate, distinct from Gymnodinium catenatum and Gymnodinium nolleri. Phycologia 38:301-313

Carty S, Cox ER (1986) Kansodinium gen. nov. and Durinskia gen. nov.: two genera of freshwater dinoflagellates (Pyrrhophyta). Phycologia 25:197-204

> Chesnick JM, Kooistra WHCF, Wellbbrock U, Medlin LK (1997) Ribosomal RNA analysis indicates a benthic pennate diatom ancestry for the endosymbionts of the dino- flagellates Peridinium foliaceum and Peridinium balticum (Pyrrhophyta). J Eukaryot Microbiol 44:314-320

$>$ Daugbjerg N, Hansen G, Larsen J, Moestrup Ø (2000) Phylogeny of some of the major genera of dinoflagellates based on ultrastructure and partial LSU rDNA sequence data, including the erection of three new genera of unarmoured dinoflagellates. Phycologia 39:302-317

- De Salas MF, Bolch CJS, Botes L, Nash G, Wright SW, Hallegraeff GM (2003) Takayama gen. nov. (Gymnodiniales, Dinophyceae), a new genus of unarmed dinoflagellates with sigmoid apical grooves, including the description of two new species. J Phycol 39:1233-1246

> De Salas MF, Bolch CJS, Hallegraeff GM (2004) Karenia umbella sp. nov. (Gymnodiniales, Dinophyceae), a new potentially ichthyotoxic dinoflagellate species from Tasmania, Australia. Phycologia 43:166-175

$>$ De Salas MF, Bolch CJS, Hallegraeff GM (2005) Karlodinium australe sp. nov. (Gymnodiniales, Dinophyceae), a new potentially ichthyotoxic unarmoured dinoflagellate from lagoonal habitats of south-eastern Australia. Phycologia 44:640-650

> De Salas MF, Laza-Martínez A, Hallegraeff GM (2008) Novel unarmored dinoflagellates from the toxigenic family Kareniaceae (Gymnodiniales): five new species of Karlodinium and one new Takayama from the Australian sector of the Southern Ocean. J Phycol 44:241-257

Delwiche CF (2007) The origin and evolution of dinoflagellates. In: Falkowski PG, Knoll AH (eds) Evolution of primary producers in the sea. Elsevier, Boston, MA, p 191-205

> Edvardsen B, Eikrem W, Throndsen J, Saez AG, Probert I, Medlin LK (2011) DNA phylogenies and a morphological revision provide the basis for a revised taxonomy of the Prymnesiales (Haptophyta). Eur J Phycol 46:202-228

Egeland ES, Eikrem W, Throndsen J, Wilhelm C, Zapata M, Liaaen-Jensen S (1995) Carotenoids from further prasinophytes. Biochem Syst Ecol 23:747-755

Egeland ES, Garrido JL, Zapata M, Maestro MA, LiaaenJensen S (2000) Algal carotenoids. Part 64. Structure and chemistry of 4-keto-19'-hexanoyloxyfucoxanthin with a novel carotenoid end group. J Chem Soc Perkin Trans 1: 1223-1230

Elbrächter M, Schnepf E (1996) Gymnodinium chlorophorum, a new, green, bloom-forming dinoflagellate (Gymnodiniales, Dinophyceae) with a vestigial prasinophyte endosymbiont. Phycologia 35:381-393

> Fawley MW (1989) A new form of chlorophyll $c$ involved in light harvesting. Plant Physiol 91:727-732

> Fraga S, Bravo I, Delgado M, Franco JM, Zapata M (1995) Gyrodinium impudicum sp. nov. (Dinophyceae), a non toxic, chain-forming, red tide dinoflagellate. Phycologia 34:514-521

Fraga S, Penna A, Bianconi I, Paz B, Zapata M (2008) Coolia canariensis sp. nov. (Dinophyceae), a new nontoxic epiphytic benthic dinoflagellate from the Canary Islands. J Phycol 44:1060-1070

- Fraga S, Rodríguez F, Caillaud A, Diogène J, Raho N, Zapata $M$ (2011) Gambierdiscus excentricus sp. nov (Dinophyceae), a benthic toxic dinoflagellate from the Canary Islands (NE Atlantic Ocean). Harmful Algae 11:10-22

> Garcés E, Fernández M, Penna A, Van Lenning K, Gutierrez A, Camp J, Zapata M (2006) Characterization of NW Mediterranean Karlodinium spp. (Dinophyceae) strains using morphological, molecular, chemical, and physiological methodologies. J Phycol 42:1096-1112

Garcia-Cuetos L, Moestrup Ø, Hansen PJ, Niels Daugbjerg 
N (2010) The toxic dinoflagellate Dinophysis acuminata harbors permanent chloroplasts of cryptomonad origin, not kleptochloroplasts. Harmful Algae 9:25-38

Garrido JL, Zapata M (1997) Reversed-phase high-performance liquid chromatography of mono- and divinyl chlorophyll forms using pyridine-containing mobile phases and polymeric octadecylsilica. Chromatographia 44:43-49

Garrido JL, Zapata M (1998) Detection of new pigments from Emiliania huxleyi (Prymnesiophyceae) by high-performance liquid chromatography, liquid chromatography-mass spectrometry, visible spectroscopy, and fast atom bombardment mass spectrometry. J Phycol 34: 70-78

Garrido JL, Zapata M (2006) Chlorophyll analysis by new HPLC methods. In: Grimm B, Porra RJ, Rüdiger W, Scheer U (eds) Chlorophylls and bacteriochlorophylls: biochemistry, biophysics, functions and applications. Advances in photosynthesis and respiration, Vol 25. Springer, Dordrecht, p 109-121

Garrido JL, Otero J, Maestro MA, Zapata M (2000) The main non-polar chlorophyll $c$ from Emiliania huxleyi (Prymnesiophyceae) is a chlorophyll $C_{2}$-monogalactosyldiacylglyceride ester: a mass spectrometry study. J Phycol 36: 497-505

Garrido JL, Rodríguez F, Zapata M (2009) Occurrence of loroxanthin, loroxanthin decenoate, and loroxanthin dodecenoate in Tetraselmis species (Prasinophyceae, Chlorophyta). J Phycol 45:366-374

Geider R, Gunter PA (1989) Evidence for the presence of phycoerythrin in Dinophysis norvegica, a pink dinoflagellate. Br Phycol J 24:195-198

Guillard RRL, Hargraves PE (1993) Stichochrysis immobilis is a diatom not a chrysophyte. Phycologia 32:234-236

Guiry MD, Guiry GM (2010) AlgaeBase. National University of Ireland, Galway. Available at: www.algaebase.org/ (accessed 5 June 2010)

> Hackett JD, Maranda L, Yoon HS, Bhattacharya D (2003) Phylogenetic evidence for the cryptophyte origin of the plastid of Dinophysis (Dinophysiales, Dinophyceae). J Phycol 39:440-448

Hallegraeff GM, Anderson DM, Cembella AD (2003) Manual of harmful marine microalgae. UNESCO, Paris

Hansen G, Botes L, De Salas M (2007) Ultrastructure and large subunit rDNA sequences of Lepidodinium viride reveal a close relationship to Lepidodinium chlorophorum comb. nov. (= Gymnodinium chlorophorum). Phycol Res 55:25-41

Helfrich M, Ross A, King GC, Turner AG, Larkum AWD (1999) Identification of [8-vinyl]-protochlorophyllide $a$ in phototrophic prokaryotes and algae: chemical and spectroscopic properties. Biochim Biophys Acta 1410:262-272

> Hewes CD, Mitchell BG, Moissan TA, Vernet M, Reid FMH (1998) The phycobilin signatures of chloroplasts from three dinoflagellate species: a microanalytical study of Dinophysis caudata, D. fortii, and D. acuminata (Dinophysiales, Dinophyceae). J Phycol 34:945-951

$>$ Higgins HW, Mackey DJ (2000) Algal class abundances, estimated from chlorophyll and carotenoid pigments, in the western Equatorial Pacific under El Niño and non-El Niño conditions. Deep-Sea Res I 47:1461-1483

Hiller RG (1999) Carotenoid as components of the light-harvesting proteins of eukaryotic algae. In: Frank HA, Young AJ, Britton G, Cogdell RJ (eds) The photochemistry of carotenoids. Kluwer Academic Publishers, Dor- drecht, p 81-98

Hofmann E, Wrench PM, Sharples FP, Hiller RG, Welte W, Diderichs K (1996) Structural basis of light harvesting by carotenoids: peridinin-chlorophyll-protein from Amphidinium carterae. Science 272:1788-1791

Horiguchi T, Pienaar RN (1992) Amphidinium latum Lebour (Dinophyceae), a sand-dwelling dinoflagellate feeding on cryptomonads. Jpn J Phycol 40:353-363

Horiguchi T, Pienaar RN (1994) Ultrastructure of a new marine sand-dwelling dinoflagellate, Gymnodinium quadrilobatum sp. nov. (Dinophyceae) with special reference to its endosymbiotic alga. Eur J Phycol 29:237-245

> Horiguchi T, Takano Y (2006) Serial replacement of a diatom endosymbiont in the marine dinoflagellate Peridinium quinquecorne (Peridiniales, Dinophyceae). Phycol Res 54:193-200

> Imanian B, Pomber JF, Keeling PJ (2010) The complete plastid genomes of the two 'dinotoms' Durinskia baltica and Kryptoperidinium foliaceum. PLoS ONE 5:e10711

> Janson S (2004) Molecular evidence that plastids in the toxin-producing dinoflagellate genus Dinophysis originate from the free-living cryptophyte Teleaulax amphioxeia. Environ Microbiol 6:1102-1106

Jeffrey SW (1997) Chlorophyll and carotenoid extinction coefficients. In: Jeffrey SW, Mantoura RFC, Wright SW (eds) Phytoplankton pigments in oceanography: guidelines to modern methods. UNESCO Publishing, Paris, p 595-596

Jeffrey SW, Mantoura RFC (1997) Pigment abbreviations used by SCOR WG 78. In: Jeffrey SW, Mantoura RFC, Wright SW (eds) Phytoplankton pigments in oceanography: guidelines to modern methods. UNESCO Publishing, Paris, p 564-565

Jeffrey SW, Vesk M (1976) Further evidence for a membrane-bound endosymbiont within the dinoflagellate Peridinium foliaceum. J Phycol 12:450-455

Jeffrey SW, Vesk M (1997) Introduction to marine phytoplankton and their pigment signatures. In: Jeffrey SW, Mantoura RFC, Wright SW (eds) Phytoplankton pigments in oceanography: guidelines to modern methods. UNESCO Publishing, Paris, p 37-84

Jeffrey SW, Wright SW (2006) Photosynthetic pigments in marine microalgae: insights from cultures and the sea. In: Subba Rao DV (ed) Algal cultures, analogues of blooms and applications. Science Publishers, Plymouth, p 33-90

Jeffrey SW, Sielicki M, Haxo FT (1975) Chloroplast pigment patterns in dinoflagellates. J Phycol 11:374-384

Jeffrey SW, Mantoura RFC, Bjørnland T (1997) Data for the identification of 47 key phytoplankton pigments. In: Jeffrey SW, Mantoura RFC, Wright SW (eds) Phytoplankton pigments in oceanography: guidelines to modern methods. UNESCO Publishing, Paris, p 449-559

Jeffrey SW, Wright SW, Zapata M (1999) Recent advances in HPLC pigment analysis of phytoplankton. Mar Freshw Res 50:879-896

> Jeong HJ, Yoo YD, Park JY, Song JY and others (2005) Feeding by phototrophic red-tide dinoflagellates: five species newly revealed and six species previously known to be mixotrophic. Aquat Microb Ecol 40:133-150

> Kempton JW, Wolny J, Tengs T, Rizzo P and others (2002) Kryptoperidinium foliaceum blooms in South Carolina: a multi-analytical approach to identification. Harmful Algae 1:383-392

Kite GC, Rothschild LJ, Dodge JD (1988) Nuclear and plas- 
tid DNAs from the binucleate dinoflagellates Glenodinium (Peridinium) foliaceum and Peridinium balticum. Biosystems 21:151-163

Koike K, Takishita K (2008) Anucleated cryptophyte vestiges in the gonyaulacalean dinoflagellates Amylax buxus and Amylax triacantha (Dinophyceae). Phycol Res 56:301-311

> Koike K, Sekiguchi H, Kobiyama A, Takishita K, Kawachi M, Koike K, Ogata T (2005) A novel type of kleptoplastidity in Dinophysis (Dinophyceae): presence of haptophyte-type plastid in Dinophysis mitra. Protist 156: 225-237

> Latasa M, Bidigare RR (1998) A comparison of phytoplankton populations of the Arabian Sea during the Spring Intermonsoon and Southwest Monsoon of 1995 as described by HPLC-analyzed pigments. Deep-Sea Res II 45:2133-2170

- Latasa M, Van Lenning K, Garrido JL, Scharek R, Estrada M, Rodríguez F, Zapata M (2001) Losses of chlorophylls and carotenoids in aqueous acetone and methanol extracts prepared for RPHPLC analysis of pigments. Chromatographia 53:385-391

> Latasa M, Scharek R, Le Gall F, Guillou L (2004) Pigment suites and taxonomic groups in Prasinophyceae. J Phycol 40:1149-1155

Letelier RM, Bidigare RR, Hebel DV, Ondrusek M, Winn CD, Karl DM (1993) Temporal variability of phytoplankton community structure based on pigment analysis. Limnol Oceanogr 38:1420-1437

Liaaen-Jensen S (1998) Carotenoids in chemosystematics. In: Britton G, Liaaen-Jensen S, Pfander H (eds) Carotenoids. Biosynthesis and metabolism, Vol 3. Birkhäuser Verlag, Basel, p 217-247

Lin S, Zhang H, Hou Y, Miranda L, Bhattacharya D (2006) Development of a dinoflagellate-oriented PCR primer set leads to detection of picoplanktonic dinoflagellates from Long Island Sound. Appl Environ Microbiol 72: 5626-5630

Mackey MD, Mackey DJ, Higgins HW, Wright SW (1996) CHEMTAX - a program for estimating class abundances from chemical markers: application to HPLC measurements of phytoplankton. Mar Ecol Prog Ser 144: 265-283

Mackey DJ, Higgins HW, Mackey MD, Holdsworth D (1998) Algal class abundances in the western equatorial Pacific: estimation from HPLC measurements of chloroplast pigments using CHEMTAX. Deep-Sea Res I 45:1441-1468

Macpherson AN, Hiller RG (2003) Light-harvesting systems in chlorophyll $c$-containing algae. In: Green BR, Parson WW (eds) Light-harvesting antennas in photosynthesis. Kluwer Academic Publishers, Dordrecht, p 323-352

Matsumoto T, Shinozaki F, Chikuni T, Yubuki A and others (2011) Green-colored plastids in the dinoflagellate genus Lepidodinium are of core cloropyhyte origin. Protist 162:268-276

- McEwan ML, Keeling PJ (2004) HSP90, tubulin and actin are retained in the tertiary endosymbiont genome of Kryptoperidinium foliaceum. J Eukaryot Microbiol 51: 651-659

> Meyer-Harms B, Pollehne F (1998) Alloxanthin in Dinophysis norvegica (Dinophysiales, Dinophyceae) from the Baltic Sea. J Phycol 34:280-285

> Minge MA, Shalchian-Tabrizi K, Tørresen OK, Takishita K and others (2010) A phylogenetic mosaic plastid proteome and unusual plastid-targeting signals in the green colored dinoflagellate Lepidodinium chlorophorum. BMC Evol Biol 10:191

- Minnhagen S, Janson S (2006) Genetic analyses of Dinophysis spp. support kleptoplastidy. FEMS Microbiol Ecol $57: 47-54$

Montresor M, Lovejoy C, Orsini L, Procaccini G, Roy S (2003) Bipolar distribution of the cyst-forming dinoflagellate Polarella glacilis. Polar Biol 26:186-194

Moon-van der Staay SY, De Wachter R, Vaulot D (2001) Oceanic 18S rDNA sequences from picoplankton reveal unsuspected eukaryotic diversity. Nature 409:607-610

> Morse D, Salois P, Markovic P, Hastings JW (1995) A nuclear-encoded form II RuBisCO in dinoflagellates. Science 268:1622-1624

- Nagai S, Nishitani G, Tomaru Y, Sakiyama S, Kamiyama T (2008) Predation by the toxic dinoflagellate Dinophysis fortii on the ciliate Myrionecta rubra and observation of sequestration of ciliate chloroplasts. J Phycol 44:909-922

Nishitani G, Nagai S, Sakiyama S, Kamiyama T (2008a) Successful cultivation of the toxic dinoflagellate Dinophysis caudata (Dinophyceae). Plankton Benthos Res 3:78-85

> Nishitani G, Nagai S, Takano Y, Sakiyama S, Baba K, Kamiyama T (2008b) Growth characteristics and phylogenetic analysis of the marine dinoflagellate Dinophysis infundibulus (Dinophyceae). Aquat Microb Ecol 52: 209-221

Park MG, Kim S, Kim HS, Myung G, Kang YG, Yih W (2006) First successful culture of the marine dinoflagellate Dinophysis acuminata. Aquat Microb Ecol 45:101-106

Pienaar RN, Sakai H, Horiguchi T (2007) Description of a new dinoflagellate with a diatom endosymbiont, Durinskia capensis sp. nov. (Peridiniales, Dinophyceae) from South Africa. J Plant Res 120:247-258

Rodríguez F, Pazos Y, Maneiro J, Zapata M (2003) Temporal variation in phytoplankton assemblages and pigment composition at a fixed station of the Ría of Pontevedra (NW Spain). Estuar Coast Shelf Sci 58:499-515

> Rodríguez F, Chauton M, Johnsen G, Andresen K, Olsen LM, Zapata M (2006) Photoacclimation in phytoplankton: implications for biomass estimates, pigment functionality and chemotaxonomy. Mar Biol 148:963-971

Rodríguez F, Escalera L, Reguera B, Rial P, Riobó P, de Jesús $\mathrm{T}$ (2012) Morphological variability, toxinology and genetics of the dinoflagellate Dinophysis tripos (Dinophysiaceae, Dinophysiales). Harmful Algae 13:26-33

> Rowan R, Whitney SM, Fowler A, Yellowlees D (1996) Rubisco in marine symbiotic dinoflagellates: form II enzymes in eukaryotic oxygenic phototrophs encoded by a nuclear multigene family. Plant Cell 8:539-553

> Saldarriaga JF, Taylor FJR, Keeling PJ, Cavalier-Smith T (2001) Dinoflagellate nuclear SSU rRNA phylogeny suggests multiple plastid losses and replacements. J Mol Evol 53:204-213

Saldarriaga JF, Taylor FJR, Cavalier-Smith T, MendenDeuer S, Keeling PJ (2004) Molecular data and the evolutionary history of dinoflagellates. Eur J Protistol 40: 85-111

Sampedro N, Fraga S, Penna A, Casabianca S and others (2011) Barrufeta bravensis gen. nov. sp. nov. (Dinophyceae) a new bloom forming species from NW Mediterranean Sea. J Phycol 47:375-392

Seoane S, Zapata M, Orive E (2009) Growth rates and pigment patterns of haptophytes isolated from estuarine waters. J Sea Res 62:286-294

Stauber JL, Jeffrey SW (1988) Photosynthetic pigments in 
fifty-one species of marine diatoms. J Phycol 24:158-172

Takano Y, Hansen G, Fujita D, Horiguchi T (2008) Serial replacement of diatom endosymbionts in two freshwater dinoflagellates, Peridiniopsis spp. Phycologia 47:41-53

Takishita K, Koike K, Maruyama T, Ogata T (2002) Molecular evidence for plastid robbery (kleptoplastidy) in Dinophysis, a dinoflagellate causing diarrhetic shellfish poisoning. Protist 153:293-302

Tamura M, Shimada S, Horiguchi T (2005) Galeidiniium rugatum gen. et sp. nov. (Dinophyceae), a new coccoid dinoflagellate with a diatom endosymbiont. J Phycol 41:658-671

Tangen K, Bjørnland T (1981) Observations on pigments and morphology of Gyrodinium aureolum Hulburt, a marine dinoflagellate containing 19'-hexanoyloxyfucoxanthin as the main carotenoid. J Plankton Res 3: 389-401

> Tengs T, Dahlberg OJ, Shalchian-Tabrizi K, Klaveness D, Rudi K, Delwiche CF, Jakobsen KS (2000) Phylogenetic analyses indicate that the 19' hexanoyloxyfucoxanthincontaining dinoflagellates have tertiary plastids of haptophyte origin. Mol Biol Evol 17:718-729

> Tillmann U, Elbrächter M, Krock B, John U, Cembella A (2009) Azadinium spinosum gen. et sp. nov. (Dinophyceae) identified as a primary producer of azaspiracid toxins. Eur J Phycol 44:63-79

Van Lenning K, Latasa M, Estrada M, Saez AG and others (2003) Pigment signatures and phylogenetic relationships of the Pavlophyceae (Haptophyta). J Phycol 39: 379-389

Vesk M, Dibbayawan TP, Vesk PA (1996) Immunogold localization of phycoerythrin in chloroplasts of Dinophysis acuminata and D. fortii (Dinophysiales, Dinophyta). Phycologia 35:234-238

Wang Y, Joly S, Morse D (2008) Phylogeny of dinoflagellate genes recently transferred to the nucleus supports a common ancestry with red algal plastid genes. J Mol Evol 66:175-184

Watanabe MM, Takeda Y, Sasa T, Inouye I, Suda S, Sawaguchi T, Chihara M (1987) A green dinoflagellate with chlorophylls $a$ and $b$ : morphology, fine structure of the chloroplast and chlorophyll composition. J Phycol 23: 382-389

Watanabe MM, Suda S, Inouye I, Sawaguchi T, Chihara M (1990) Lepidodinium viride gen. et sp. nov. (Gymnodiales, Dinophyta), a green dinoflagellate with a chlorophyll $a$ - and $b$-containing endosymbiont. J Phycol 26: 741-751

Withers NW, Cox ER, Tomas R, Haxo FT (1977) Pigments of

Editorial responsibility: Katherine Richardson, Copenhagen, Denmark the dinoflagellate Peridinium balticum and its photosynthetic endosymbiont. J Phycol 13:354-358

Wright SW, van den Enden RL (2000) Phytoplankton community structure and stocks in the East Australian marginal ice zone (BROKE survey, January-March 1996) determined by CHEMTAX analysis of HPLC pigment signatures. Deep-Sea Res II 47:2363-2400

- Wright SW, Thomas DP, Marchant HJ, Higgins HW, Mackey MD, Mackey DJ (1996) Analysis of phytoplankton of the Australian sector of the Southern Ocean: comparisons of microscopy and size frequency data with interpretations of pigment HPLC data using the 'CHEMTAX' matrix factorisation program. Mar Ecol Prog Ser 144:285-298

Wright SW, Ishikawa A, Marchant HJ, Davidson AT, van den Enden RL, Nash GV (2009) Composition and significance of picophytoplankton in Antarctic waters. Polar Biol 32:797-808

Yoshii Y (2006) Diversity and evolution of photosynthetic antenna systems in green plants. Phycol Res 54:220-229

Zapata M (2005) Recent advances in pigment analysis as applied to picophytoplankton. Vie Milieu 55:233-248

> Zapata M, Garrido JL (1991) Influence of injection conditions in reversed-phase high-performance liquid chromatography of chlorophylls and carotenoids. Chromatographia 31:589-594

Zapata M, Rodríguez F, Garrido JL (2000) Separation of chlorophylls and carotenoids from marine phytoplankton: a new HPLC method using a reversed phase $\mathrm{C}_{8}$ column and pyridine-containing mobile phases. Mar Ecol Prog Ser 195:29-45

Zapata M, Edvardsen B, Rodríguez F, Maestro MA, Garrido JL (2001) Chlorophyll $C_{2}$ monogalactosyldiacylglyceride ester (chl $C_{2}$-MGDG). A novel marker pigment for Chrysochromulina species (Haptophyta). Mar Ecol Prog Ser 219:85-98

Zapata M, Jeffrey SW, Wright SW, Rodríguez F, Garrido JL, Clementson L (2004) Photosynthetic pigments in 37 species (65 strains) of Haptophyta: implications for oceanography and chemotaxonomy. Mar Ecol Prog Ser 270: 83-102

Zapata M, Garrido JL, Jeffrey SW (2006) Chlorophyll c pigments: current status. In: Grimm B, Porra RJ, Rüdiger W, Scheer U (eds) Chlorophylls and bacteriochlorophylls: biochemistry, biophysics, functions and applications. Advances in photosynthesis and respiration, Vol 25. Springer, Dordrecht, p 39-53

Zhang Z, Green BR, Cavalier-Smith T (1999) Single gene circles in dinoflagellate chloroplast genomes. Nature 400:155-159

Submitted: October 25, 2011; Accepted: June 18, 2012

Proofs received from author(s): September 14, 2012
In Memoriam. While this paper was being reviewed, our colleague and friend Manuel Zapata passed away. He contributed greatly to the present state of knowledge of algal pigments (on their structures, methods of analysis, taxonomical distribution and use as signatures for characterizing natural phytoplankton communities). His HPLC method for algal pigments (Zapata et al. 2000; see Literature Cited) has become a standard procedure in marine laboratories around the world. 'Zapa', as his family and friends called him affectionately, left us an important body of knowledge and a special way to observe nature. We will always remember him.

Photo:

Courtesy of Andrea Zapata-Girau

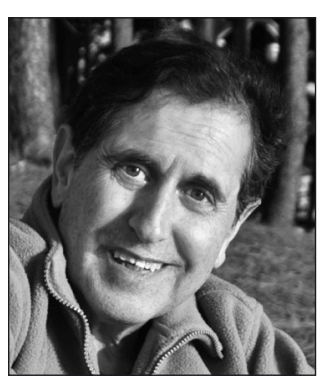

